\title{
Organic nitrate chemistry and its implications for nitrogen budgets in an isoprene- and monoterpene-rich atmosphere: constraints from aircraft (SEAC $\left.{ }^{4} \mathrm{RS}\right)$ and ground-based (SOAS) observations in the Southeast US
}

Jenny A. Fisher ${ }^{1,2}$, Daniel J. Jacob ${ }^{3,4}$, Katherine R. Travis ${ }^{3}$, Patrick S. Kim ${ }^{4}$, Eloise A. Marais ${ }^{3}$, Christopher Chan Miller $^{4}$, Karen Yu ${ }^{3}$, Lei Zhu ${ }^{3}$, Robert M. Yantosca ${ }^{3}$, Melissa P. Sulprizio ${ }^{3}$, Jingqiu Mao ${ }^{5,6}$, Paul O. Wennberg ${ }^{7,8}$, John D. Crounse ${ }^{7}$, Alex P. Teng ${ }^{7}$, Tran B. Nguyen ${ }^{7, a}$, Jason M. St. Clair ${ }^{7, b}$, Ronald C. Cohen ${ }^{9,10}$, Paul Romer ${ }^{9}$, Benjamin A. Nault $^{10, \mathrm{c}}$, Paul J. Wooldridge ${ }^{9}$, Jose L. Jimenez ${ }^{11,12}$, Pedro Campuzano-Jost ${ }^{11,12}$, Douglas A. Day ${ }^{11,12}$, Weiwei Hu$^{11,12}$, Paul B. Shepson ${ }^{13,14}$, Fulizi Xiong ${ }^{13}$, Donald R. Blake ${ }^{15}$, Allen H. Goldstein ${ }^{16,17}$, Pawel K. Misztal ${ }^{16}$, Thomas F. Hanisco $^{18}$, Glenn M. Wolfe ${ }^{18,19}$, Thomas B. Ryerson ${ }^{20}$, Armin Wisthaler ${ }^{21,22}$, and Tomas Mikoviny ${ }^{21}$

${ }^{1}$ Centre for Atmospheric Chemistry, School of Chemistry, University of Wollongong, Wollongong, NSW, Australia

${ }^{2}$ School of Earth and Environmental Sciences, University of Wollongong, Wollongong, NSW, Australia

${ }^{3}$ Harvard John A. Paulson School of Engineering and Applied Sciences, Harvard University, Cambridge, MA, USA

${ }^{4}$ Department of Earth and Planetary Sciences, Harvard University, Cambridge, MA, USA

${ }^{5}$ Program in Atmospheric and Oceanic Sciences, Princeton University, Princeton, NJ, USA

${ }^{6}$ Geophysical Fluid Dynamics Laboratory/National Oceanic and Atmospheric Administration, Princeton, NJ, USA

${ }^{7}$ Division of Geological and Planetary Sciences, California Institute of Technology, Pasadena, CA, USA

${ }^{8}$ Division of Engineering and Applied Science, California Institute of Technology, Pasadena, CA, USA

${ }^{9}$ Department of Chemistry, University of California at Berkeley, Berkeley, CA, USA

${ }^{10}$ Department of Earth and Planetary Science, University of California at Berkeley, Berkeley, CA, USA

${ }^{11}$ Department of Chemistry and Biochemistry, University of Colorado, Boulder, CO, USA

${ }^{12}$ Cooperative Institute for Research in Environmental Sciences, University of Colorado, Boulder, CO, USA

${ }^{13}$ Department of Chemistry, Purdue University, West Lafayette, IN, USA

${ }^{14}$ Department of Earth, Atmospheric and Planetary Sciences, Purdue University, West Lafayette, IN, USA

${ }^{15}$ Department of Chemistry, University of California Irvine, Irvine, CA, USA

${ }^{16}$ Department of Environmental Science, Policy, and Management, University of California at Berkeley, Berkeley, CA, USA

${ }^{17}$ Department of Civil and Environmental Engineering, University of California at Berkeley, Berkeley, CA, USA

${ }^{18}$ Atmospheric Chemistry and Dynamics Laboratory, NASA Goddard Space Flight Center, Greenbelt, MD, USA

${ }^{19}$ Joint Center for Earth Systems Technology, University of Maryland Baltimore County, Baltimore, MD, USA

${ }^{20}$ Chemical Sciences Division, Earth System Research Lab, National Oceanic and Atmospheric Administration, Boulder, CO, USA

${ }^{21}$ Department of Chemistry, University of Oslo, Oslo, Norway

${ }^{22}$ Institute for Ion Physics and Applied Physics, University of Innsbruck, Innsbruck, Austria

${ }^{a}$ now at: Department of Environmental Toxicology, University of California at Davis, Davis, CA, USA

${ }^{b}$ now at: Atmospheric Chemistry and Dynamics Laboratory, NASA Goddard Space Flight Center, Greenbelt, MD, USA and Joint Center for Earth Systems Technology, University of Maryland Baltimore County, Baltimore, MD, USA

${ }^{c}$ now at: Department of Chemistry and Biochemistry and Cooperative Institute for Research in Environmental Sciences, University of Colorado, Boulder, CO, USA

Correspondence to: Jenny A. Fisher (jennyf@uow.edu.au)

Received: 18 January 2016 - Published in Atmos. Chem. Phys. Discuss.: 4 February 2016

Revised: 27 April 2016 - Accepted: 29 April 2016 - Published: 17 May 2016

Published by Copernicus Publications on behalf of the European Geosciences Union. 


\begin{abstract}
Formation of organic nitrates $\left(\mathrm{RONO}_{2}\right)$ during oxidation of biogenic volatile organic compounds (BVOCs: isoprene, monoterpenes) is a significant loss pathway for atmospheric nitrogen oxide radicals $\left(\mathrm{NO}_{x}\right)$, but the chemistry of $\mathrm{RONO}_{2}$ formation and degradation remains uncertain. Here we implement a new BVOC oxidation mechanism (including updated isoprene chemistry, new monoterpene chemistry, and particle uptake of $\mathrm{RONO}_{2}$ ) in the GEOSChem global chemical transport model with $\sim 25 \times 25 \mathrm{~km}^{2}$ resolution over North America. We evaluate the model using aircraft (SEAC $\left.{ }^{4} \mathrm{RS}\right)$ and ground-based (SOAS) observations of $\mathrm{NO}_{x}, \mathrm{BVOCs}$, and $\mathrm{RONO}_{2}$ from the Southeast US in summer 2013. The updated simulation successfully reproduces the concentrations of individual gas- and particlephase $\mathrm{RONO}_{2}$ species measured during the campaigns. Gasphase isoprene nitrates account for $25-50 \%$ of observed $\mathrm{RONO}_{2}$ in surface air, and we find that another $10 \%$ is contributed by gas-phase monoterpene nitrates. Observations in the free troposphere show an important contribution from long-lived nitrates derived from anthropogenic VOCs. During both campaigns, at least $10 \%$ of observed boundary layer $\mathrm{RONO}_{2}$ were in the particle phase. We find that aerosol uptake followed by hydrolysis to $\mathrm{HNO}_{3}$ accounts for $60 \%$ of simulated gas-phase $\mathrm{RONO}_{2}$ loss in the boundary layer. Other losses are $20 \%$ by photolysis to recycle $\mathrm{NO}_{x}$ and $15 \%$ by dry deposition. $\mathrm{RONO}_{2}$ production accounts for $20 \%$ of the net regional $\mathrm{NO}_{x}$ sink in the Southeast US in summer, limited by the spatial segregation between BVOC and $\mathrm{NO}_{x}$ emissions. This segregation implies that $\mathrm{RONO}_{2}$ production will remain a minor sink for $\mathrm{NO}_{x}$ in the Southeast US in the future even as $\mathrm{NO}_{x}$ emissions continue to decline.
\end{abstract}

\section{Introduction}

Nitrogen oxide radicals $\left(\mathrm{NO}_{x} \equiv \mathrm{NO}+\mathrm{NO}_{2}\right)$ are critical in controlling tropospheric ozone production (Monks et al., 2015, and references therein) and influencing aerosol formation (Rollins et al., 2012; Ayres et al., 2015; Xu et al., 2015), with indirect impacts on atmospheric oxidation capacity, air quality, climate forcing, and ecosystem health. The ability of $\mathrm{NO}_{x}$ to influence ozone and aerosol budgets is tied to its atmospheric fate. In continental regions, a significant loss pathway for $\mathrm{NO}_{x}$ is reaction with peroxy radicals derived from biogenic volatile organic compounds (BVOCs) to form organic nitrates (Liang et al., 1998; Browne and Cohen, 2012). $\mathrm{NO}_{x}$ loss to organic nitrate formation is predicted to become increasingly important as $\mathrm{NO}_{x}$ abundance declines (Browne and Cohen, 2012), as has occurred in the US over the past 2 decades (Hidy et al., 2014; Simon et al., 2015). Despite this increasing influence on the $\mathrm{NO}_{x}$ budget, the chemistry of organic nitrates remains the subject of debate, with key uncertainties surrounding the organic nitrate yield from BVOC oxidation, the recycling of $\mathrm{NO}_{x}$ from organic nitrate degradation, and the role of organic nitrates in secondary organic aerosol formation (Paulot et al., 2012; Perring et al., 2013). Two campaigns in the Southeast US in summer 2013 provided data sets of unprecedented chemical detail for addressing these uncertainties: the airborne NASA SEAC ${ }^{4} \mathrm{RS}$ (Studies of Emissions and Atmospheric Composition, Clouds, and Climate Coupling by Regional Surveys; Toon et al., 2016) and the ground-based SOAS (Southern Oxidants and Aerosols Study). Here we use a $\sim 25 \times 25 \mathrm{~km}^{2}$ resolution 3-D chemical transport model (GEOS-Chem) to interpret organic nitrate observations from both campaigns, with focus on their impacts on atmospheric nitrogen $(\mathrm{N})$ budgets.

Nitrogen oxides are emitted from natural and anthropogenic sources primarily as NO, which rapidly achieves steady state with $\mathrm{NO}_{2}$. Globally, the dominant loss pathway for $\mathrm{NO}_{x}$ is reaction with the hydroxyl radical $(\mathrm{OH})$ to form nitric acid $\left(\mathrm{HNO}_{3}\right)$. In the presence of VOCs, $\mathrm{NO}_{x}$ can also be lost by reaction with organic peroxy radicals $\left(\mathrm{RO}_{2}\right)$ to form peroxy nitrates $\left(\mathrm{RO}_{2} \mathrm{NO}_{2}\right)$ and alkyl and multifunctional nitrates $\left(\mathrm{RONO}_{2}\right)(\mathrm{O}$ 'Brien et al., 1995). Their daytime formation temporarily sequesters $\mathrm{NO}_{x}$, facilitating its export to more remote environments (Horowitz et al., 1998; Paulot et al., 2012; Mao et al., 2013). $\mathrm{RO}_{2} \mathrm{NO}_{2}$ species are thermally unstable at boundary layer temperatures and decompose back to $\mathrm{NO}_{x}$ on a timescale of minutes, except for the longer-lived peroxyacylnitrates (PANs) (Singh and Hanst, 1981). $\mathrm{RONO}_{2}$ species can dominate $\mathrm{NO}_{x}$ loss when BVOC emissions are high and $\mathrm{NO}_{x}$ emissions are low (Browne and Cohen, 2012; Paulot et al., 2012; Browne et al., 2014) and may be more efficient for reactive $\mathrm{N}$ export than PANs (Mao et al., 2013). The amount of $\mathrm{NO}_{x}$ sequestered by $\mathrm{RONO}_{2}$ depends on the interplay between BVOC and $\mathrm{NO}_{x}$ emissions, the $\mathrm{RONO}_{2}$ yield from BVOC oxidation, and the eventual $\mathrm{RONO}_{2}$ fate.

$\mathrm{RONO}_{2}$ chemistry and impacts are illustrated schematically in Fig. 1, starting from reaction of $\mathrm{NO}_{x}$ with BVOCs (mainly isoprene and monoterpenes) to form $\mathrm{RONO}_{2}$. The $\mathrm{RONO}_{2}$ yield $(\alpha)$ from isoprene oxidation by $\mathrm{OH}$ has been inferred from laboratory and field experiments to be 4-15\% (Tuazon and Atkinson, 1990; Chen et al., 1998; Sprengnether et al., 2002; Patchen et al., 2007; Perring et al., 2009a; Paulot et al., 2009; Nguyen et al., 2014; Xiong et al., 2015). Models have shown nearly this full range of yields to be compatible with $\mathrm{RONO}_{2}$ observations, depending on the chemical mechanism assumed. For example, two models using different isoprene reaction schemes both successfully reproduced observations from a 2004 aircraft campaign (ICARTT) - one assuming a $4 \%$ molar yield (Horowitz et al., 2007) and the other assuming an $11.7 \%$ molar yield (Mao et al., 2013). The $\mathrm{RONO}_{2}$ yield from monoterpene oxidation by $\mathrm{OH}$ is even more uncertain. Laboratory measurements exist only for $\alpha$-pinene, and these show divergent results: $26 \%$ 


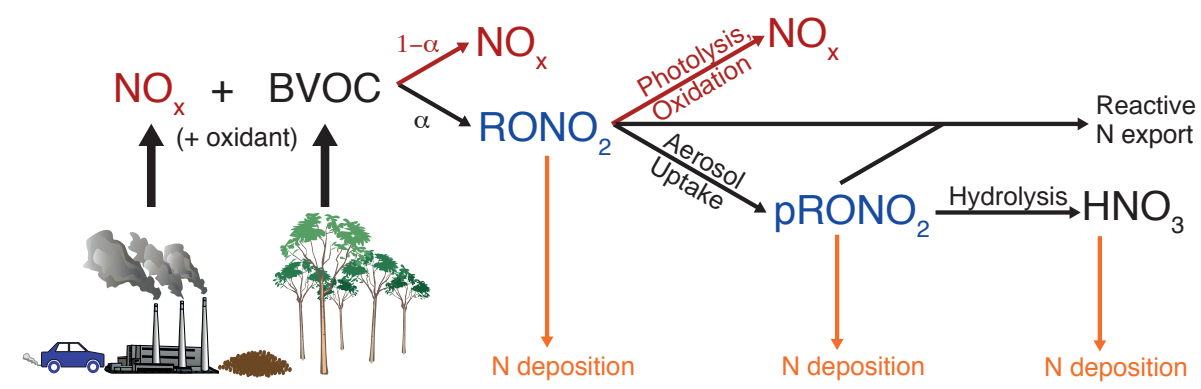

Figure 1. Schematic representation of organic nitrate chemistry and impacts. Organic nitrates are shown in blue, $\mathrm{NO}_{x}$ and processes that recycle $\mathrm{NO}_{x}$ are shown in red, and nitrogen deposition is shown in orange. Symbols courtesy of the Integration and Application Network, University of Maryland Center for Environmental Science (ian.umces.edu/symbols/).

(Rindelaub et al., 2015), $18 \%$ (Nozière et al., 1999), and $1 \%$ (Aschmann et al., 2002, a lower limit due to significant wall losses). $\mathrm{RONO}_{2}$ yields remain a significant uncertainty in BVOC oxidation schemes, with implications for their impacts on $\mathrm{NO}_{x}$ sequestration.

The fate of $\mathrm{RONO}_{2}$ is of central importance in determining whether sequestered $\mathrm{NO}_{x}$ is returned to the atmosphere or removed irreversibly. Many first generation $\mathrm{RONO}_{2}$ (i.e., those formed from $\mathrm{NO}$ reaction with BVOC-derived peroxy radicals) have a short lifetime against further oxidation to form a suite of second generation $\mathrm{RONO}_{2}$ (Beaver et al., 2012; Mao et al., 2013; Browne et al., 2014), especially if they are produced from di-olefins such as isoprene or limonene. Laboratory studies indicate little $\mathrm{NO}_{x}$ release during this process (Lee et al., 2014); however, $\mathrm{NO}_{x}$ can be recycled by subsequent oxidation and photolysis of second generation species (Müller et al., 2014). Estimates of the $\mathrm{NO}_{x}$ recycling efficiency, defined as the mean molar percentage of $\mathrm{RONO}_{2}$ loss that releases $\mathrm{NO}_{x}$, range from $<5 \%$ to $>50 \%$ for isoprene nitrates (INs) (Horowitz et al., 2007; Paulot et al., 2009), and best estimates depend on assumptions about the IN yield (Perring et al., 2009a). $\mathrm{NO}_{x}$ recycling efficiencies from monoterpene nitrates (MTNs) have not been observed experimentally, but model sensitivity studies have shown a $14 \%$ difference in boundary layer $\mathrm{NO}_{x}$ between scenarios assuming $0 \%$ vs. $100 \%$ recycling (assuming an initial $18 \%$ MTN yield, Browne et al., 2014). Uncertainty in the $\mathrm{NO}_{x}$ recycling efficiency has a bigger impact on simulation of $\mathrm{NO}_{x}$ and ozone than uncertainty in the $\mathrm{RONO}_{2}$ yield (Xie et al., 2013).

Organic nitrates are more functionalized and less volatile than their BVOC precursors and are therefore more likely to partition to the particle phase. In the Southeast US, Xu et al. (2015) recently showed that particulate $\mathrm{RONO}_{2}\left(\mathrm{pRONO}_{2}\right)$ make an important contribution to total organic aerosol (5$12 \%$ ), consistent with in situ observations from other environments (Brown et al., 2009, 2013; Fry et al., 2013; Rollins et al., 2012, 2013). Chamber experiments have shown high mass yields of aerosol from $\mathrm{NO}_{3}$-initiated oxidation of isoprene (15-25\%; $\mathrm{Ng}$ et al., 2008; Rollins et al., 2009) and some monoterpenes (33-65\%; Fry et al., 2014). There is evidence that $\mathrm{RONO}_{2}$ from $\mathrm{OH}$-initiated oxidation also form aerosol, although with lower yields, possibly via multifunctionalized oxidation products (Kim et al., 2012; Lin et al., 2012; Rollins et al., 2012; Lee et al., 2014). $\mathrm{pRONO}_{2}$ are removed either by deposition or by hydrolysis to form $\mathrm{HNO}_{3}$ (Jacobs et al., 2014; Rindelaub et al., 2015). Both losses augment $\mathrm{N}$ deposition to ecosystems (Lockwood et al., 2008). Aerosol partitioning competes with photochemistry as a loss for gas-phase $\mathrm{RONO}_{2}$ with impacts for $\mathrm{NO}_{x}$ recycling. Partitioning also competes with gas-phase deposition, and because lifetimes against deposition are much longer for organic aerosols than for gas-phase precursors (Wainwright et al., 2012; Knote et al., 2015), this process may shift the enhanced $\mathrm{N}$ deposition associated with $\mathrm{RONO}_{2}$ (Zhang et al., 2012; Nguyen et al., 2015) to ecosystems further downwind of sources.

The 2013 SEAC $^{4} \mathrm{RS}$ and SOAS campaigns provide a unique resource for evaluating the impact of BVOC-derived organic nitrates on atmospheric $\mathrm{NO}_{x}$. Both campaigns provided data sets of unprecedented chemical detail, including isoprene, monoterpenes, total and particle-phase $\mathrm{RONO}_{2}$, and speciated INs; during SOAS these were further augmented by measurements of MTNs. Continuous measurements from the SOAS ground site provide high temporal resolution and constraints on diurnal variability (e.g., Nguyen et al., 2015; Xiong et al., 2015). These are complemented by extensive boundary layer profiling across a range of chemical environments from the SEAC ${ }^{4} \mathrm{RS}$ airborne measurements (Toon et al., 2016). Combined, the campaigns covered the summer period when BVOC emissions in the Southeast US are at a maximum (Palmer et al., 2006). These data offer new constraints for testing models of organic nitrate chemistry, with implications for our understanding of $\mathrm{NO}_{x}$, ozone, and aerosol budgets in BVOC-dominated environments worldwide.

We examine here the impact of BVOC oxidation on atmospheric $\mathrm{NO}_{x}$, using the 2013 campaign data combined with the GEOS-Chem model. The version of GEOS-Chem used in this work represents a significant advance over previ- 
ous studies, with higher spatial resolution $\left(\sim 25 \times 25 \mathrm{~km}^{2}\right)$ that better captures the spatial segregation of BVOC and $\mathrm{NO}_{x}$ emissions (Yu et al., 2016); updated isoprene nitrate chemistry incorporating new experimental and theoretical findings (e.g., Lee et al., 2014; Müller et al., 2014; Peeters et al., 2014; Xiong et al., 2015); addition of monoterpene nitrate chemistry (Browne et al., 2014; Pye et al., 2015); and consideration of particle uptake of gas-phase isoprene and monoterpene nitrates. We first evaluate the updated GEOSChem simulation using SOAS and SEAC ${ }^{4}$ RS observations of BVOCs, organic nitrates, and related species. We then use GEOS-Chem to quantify the fates of BVOC-derived organic nitrates in the Southeast US. Finally, we investigate the impacts of organic nitrate formation on the $\mathrm{NO}_{x}$ budget.

\section{Updates to GEOS-Chem simulation of organic nitrates}

We use a new high-resolution version of the GEOS-Chem CTM (www.geos-chem.org) v9-02, driven by assimilated meteorology from the NASA Global Modeling and Assimilation Office (GMAO) Goddard Earth Observing System Forward Processing (GEOS-FP) product. The model is run in a nested configuration (Wang et al., 2004), with a native GEOS-FP horizontal resolution of $0.25^{\circ}$ latitude by $0.3125^{\circ}$ longitude over North America $\left(130-60^{\circ} \mathrm{W}, 9.75-60^{\circ} \mathrm{N}\right)$. Boundary conditions are provided from a $4^{\circ} \times 5^{\circ}$ global simulation, also using GEOS-Chem. The native GEOS-FP product includes 72 vertical layers of which $\sim 38$ are in the troposphere. Temporal resolution of GEOS-FP is hourly for surface variables and 3-hourly for all others. Our simulations use a time step of $5 \mathrm{~min}$ for transport and $10 \mathrm{~min}$ for emissions and chemistry.

GEOS-Chem has been applied previously to simulation of organic nitrates in the Southeast US (e.g., Fiore et al., 2005; Zhang et al., 2011; Mao et al., 2013). Mao et al. (2013) recently updated the GEOS-Chem isoprene oxidation mechanism to include explicit production and loss of a suite of second generation isoprene nitrates and nighttime oxidation by nitrate radicals. While their updated simulation showed good agreement with aircraft observations from the 2004 ICARTT campaign over the eastern US, we find that the more detailed chemical payloads available during SOAS and SEAC ${ }^{4} \mathrm{RS}$ highlight deficiencies in that mechanism, resulting in large model biases in $\mathrm{RONO}_{2}$.

A major component of this work is modification of the organic nitrate simulation in GEOS-Chem. Our focus here is on the BVOC-derived nitrates for which field measurements are newly available. GEOS-Chem simulation of PANs was recently updated by Fischer et al. (2014) and is not discussed here. Our improvements to the $\mathrm{RONO}_{2}$ simulation are detailed below and include updates to isoprene oxidation chemistry, addition of monoterpene oxidation chemistry, and inclusion of aerosol uptake of $\mathrm{RONO}_{2}$ followed by particle- phase hydrolysis. Other updates from GEOS-Chem v9-02 and comparison to Southeast US observations are presented in several companion papers. Kim et al. (2015) describe the aerosol simulation and Travis et al. (2016) the gas-phase oxidant chemistry. Constraints on isoprene emissions from satellite formaldehyde observations are described by Zhu et al. (2016). The low- $\mathrm{NO}_{x}$ isoprene oxidation pathway and implications for organic aerosols are described by Marais et al. (2016). Finally, Yu et al. (2016) evaluate the impact of model resolution and spatial segregation of $\mathrm{NO}_{x}$ and $\mathrm{BVOC}$ emissions on isoprene oxidation. Our simulation is identical to that used in Travis et al. (2016), Yu et al. (2016), and Zhu et al. (2016).

\subsection{Isoprene oxidation chemical mechanism}

The basic structure of the GEOS-Chem isoprene oxidation mechanism is described by Mao et al. (2013), with updates to low-NO $\mathrm{N}_{x}$ pathways described and validated by Travis et al. (2016). All updates to the isoprene oxidation mechanism are provided in Travis et al. (2016) Tables S1 and S2. Figure 2 shows our updated implementation of $\mathrm{OH}$-initiated isoprene oxidation in the presence of $\mathrm{NO}_{x}$ leading to isoprene nitrate (IN) formation. Isoprene oxidation by $\mathrm{OH}$ produces isoprene peroxy radicals $\left(\mathrm{ISOPO}_{2}\right)$ in either $\beta$ - or $\delta$-hydroxy peroxy configurations depending on the location of $\mathrm{OH}$ addition. In the presence of $\mathrm{NO}_{x}, \mathrm{ISOPO}_{2}$ reacts with $\mathrm{NO}$ to either produce $\mathrm{NO}_{2}$ (the dominant fate; Perring et al., 2013) or form INs, with the yield of INs $(\alpha)$ defined as the branching ratio between these two channels. Early laboratory measurements of $\alpha$ suggested an IN yield between 4.4 and $12 \%$ (Tuazon and Atkinson, 1990; Chen et al., 1998; Sprengnether et al., 2002; Patchen et al., 2007; Paulot et al., 2009; Lockwood et al., 2010). More recent experiments indicate continuing uncertainty in $\alpha$, with a measured yield of $\alpha=9 \pm 4 \%$ from the Purdue Chemical Ionization Mass Spectrometer (CIMS; Xiong et al., 2015) and $\alpha=13 \pm 2 \%$ from the Caltech $\mathrm{CF}_{3} \mathrm{O}^{-}$Time-of-Flight CIMS (CIT-ToF-CIMS; Teng et al., 2016), despite excellent agreement during calibrated intercomparison exercises using one isoprene nitrate isomer (4,3 ISOPN). The sensitivity of the CIT-ToF-CIMS is similar for all isomers of ISOPN (Lee et al., 2014), while the Purdue instrument is less sensitive to the major isomer $(1,2$ ISOPN) (Xiong et al., 2015). Here, we use a first generation IN yield of $\alpha=9 \%$, which we find provides a reasonable simulation of the SOAS observations and is also consistent with the SOAS box model simulations of Xiong et al. (2015). We discuss the model sensitivity to the choice of $\alpha$ in Sect. 3 .

For the oxidation of isoprene by $\mathrm{OH}$, the mechanism described in Mao et al. (2013) assumed a first generation IN composition of $40 \% \beta$-hydroxyl INs ( $\beta$-ISOPN) and $60 \%$ $\delta$-hydroxyl INs ( $\delta$-ISOPN). However, new theoretical constraints show that under atmospheric conditions, $\delta$-channel peroxy radicals are only a small fraction of the total due to fast redissociation of peroxy radicals that fosters interconver- 


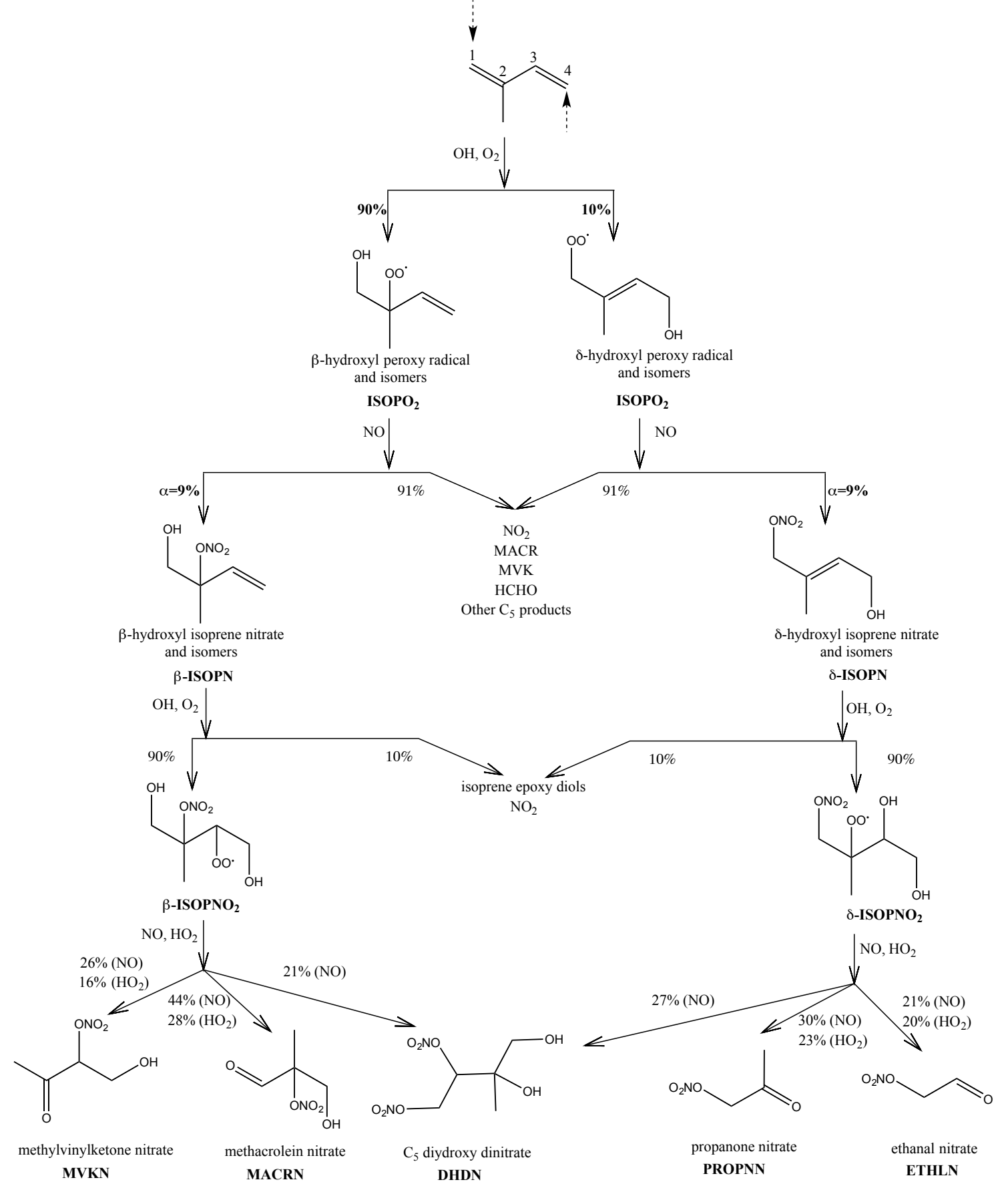

Figure 2. Schematic of the formation of isoprene nitrates (INs) from OH-initiated isoprene oxidation as implemented in GEOS-Chem. The isomers shown are indicative as the mechanism does not distinguish between isomers (except for $\beta$ - vs. $\delta$-configurations). For ISOPNO 2 oxidation, only IN products are shown, along with their yields from both $\mathrm{NO}$ and $\mathrm{HO}_{2}$ pathways. Small yields $(<10 \%)$ of $\mathrm{MVKN}$ and MACRN from $\delta$-ISOPNO 2 are not shown.

sion between isomers and tends towards an equilibrium population with more than $95 \% \beta$-isomers (Peeters et al., 2014). Using a simplified box model based on the extended Leuven Isoprene Mechanism, LIM1, we found $\delta$-isomers were $4-8 \%$ of the total peroxy pool in representative Southeast
US boundary layer conditions (temperature $\sim 295-300 \mathrm{~K}$, $\mathrm{ISOPO}_{2}$ lifetime $\sim 20-60 \mathrm{~s}$ ). In what follows, we use an IN distribution of $90 \% \beta$-ISOPN and $10 \% \delta$-ISOPN. Our box modeling suggests $10 \%$ is an upper limit for the $\delta$-ISOPN pool; however, we maintain this value as it allows improved 
simulation of species with predominantly $\delta$-pathway origins, including glyoxal and the second generation INs propanone nitrate (PROPNN) and ethanal nitrate (ETHLN).

First generation ISOPN isomers formed via $\mathrm{OH}$ oxidation of isoprene have a short photochemical lifetime against atmospheric oxidation (Paulot et al., 2009; Lockwood et al., 2010; Lee et al., 2014). Here we use updated reaction rate constants and products from Lee et al. (2014) that increase the $\beta$-ISOPN $+\mathrm{OH}$ reaction by roughly a factor of 2 and decrease ozonolysis by 3 orders of magnitude (relative to the previous mechanism based on Lockwood et al., 2010; Paulot et al., 2009). Changes in $\delta$-ISOPN reaction rate constants are more modest but in the same direction. For both isomers, reaction with $\mathrm{OH}$ forms a peroxy radical $\left(\mathrm{ISOPNO}_{2}\right)$ along with a small $(10 \%)$ yield of isoprene epoxy diols (Jacobs et al., 2014). Rate constants and products of the subsequent oxidation of $\mathrm{ISOPNO}_{2}$ to form a suite of second generation INs follow the Lee et al. (2014) mechanism. We explicitly simulate methylvinylketone nitrate (MVKN) and methacrolein nitrate (MACRN), which are primarily from the $\beta$-pathway; PROPNN and ETHLN, which are primarily from the $\delta$-pathway (and $\mathrm{NO}_{3}$-initiated oxidation); and $\mathrm{C}_{5}$ dihydroxy dinitrate (DHDN), formed from both isomers (Lee et al., 2014).

Isoprene reaction with $\mathrm{NO}_{3}$ is the dominant isoprene sink at night and can also be significant during the day (Ayres et al., 2015), producing INs with high yield (Perring et al., 2009b; Rollins et al., 2009). This reaction can account for more than $20 \%$ of isoprene loss in some environments (Brown et al., 2009) and may explain 40-50\% of total $\mathrm{RONO}_{2}$ in the southeast (Mao et al., 2013; Xie et al., 2013). The mechanism used here is identical to that described by Mao et al. (2013). Reaction of isoprene with $\mathrm{NO}_{3}$ forms a nitrooxy peroxy radical $\left(\mathrm{INO}_{2}\right)$. Subsequent reaction of $\mathrm{INO}_{2}$ with $\mathrm{NO}, \mathrm{NO}_{3}$, itself, or other peroxy radicals forms a first generation $\mathrm{C}_{5}$ carbonyl nitrate (ISN1) with $70 \%$ yield, while reaction with $\mathrm{HO}_{2}$ forms a $\mathrm{C}_{5}$ nitrooxy hydroperoxide (INPN) with $100 \%$ yield. In this simplified scheme, we do not distinguish between $\beta$ - and $\delta$-isomers for ISN1 and INPN, nor do we include the $\mathrm{C}_{5}$ hydroxy nitrate species recently identified in chamber experiments (Schwantes et al., 2015). Mao et al. (2013) lumped all second generation nitrates derived from ISN1 and INPN into a single species $\left(\mathrm{R}_{4} \mathrm{~N}_{2}\right)$, but here we assume that the lumped species is PROPNN on the basis of recent chamber experiments that show PROPNN to be a high-yield photooxidation product of INs from $\mathrm{NO}_{3}$-initiated oxidation (Schwantes et al., 2015). This effectively assumes instantaneous conversion of INs to PROPNN, a simplification that results in a shift in the simulated diurnal cycle of PROPNN (see Sect. 3). We do not include here the nitrooxy hydroxyepoxide product recently identified by Schwantes et al. (2015).

Possible fates for second generation INs include further oxidation, photolysis, uptake to the aerosol phase followed by hydrolysis (Sect. 2.3), and removal via wet and dry de- position. Müller et al. (2014) show that photolysis is likely significantly faster than reaction with $\mathrm{OH}$ for carbonyl nitrates (e.g., MVKN, MACRN, ETHLN, PROPNN) due to enhanced absorption cross sections and high quantum yields caused by the proximity of the carbonyl group (a strongly absorbing chromophore) to the weakly bound nitrate group. Here we increase the absorption cross sections of the carbonyl INs following the methodology of Müller et al. (2014, Sect. 2). Briefly, we first use the PROPNN cross section measured by Barnes et al. (1993) to calculate a wavelengthdependent cross section enhancement ratio $\left(r_{n k}\right)$, defined as the ratio of the measured cross section to the sum of the IUPAC-recommended cross sections for associated monofunctional nitrates and ketones. We then calculate new cross sections for ETHLN, MVKN, and MACRN by multiplying $r_{n k}$ by the sum of cross sections from appropriate monofunctional analogs (Table S5). The new cross sections are 515 times larger than in the original model, which used the IUPAC-recommended cross section of the monofunctional analog tert-butyl nitrate for all carbonyl nitrates (Roberts and Fajer, 1989). For all species, we calculate photolysis rates assuming unity quantum yields, whereby the weak $\mathrm{O}$ $\mathrm{NO}_{2}$ bond dissociates upon a rearrangement after photon absorption to the carbonyl chromophore (Müller et al., 2014). Peak midday photolysis rates now range from $\sim 3 \times 10^{-5} \mathrm{~s}^{-1}$ (PROPNN) to $\sim 3 \times 10^{-4} \mathrm{~s}^{-1}$ (MACRN).

Removal by dry deposition has been updated based on new observations from the SOAS ground site. The dry deposition calculation is now constrained to match observed deposition velocities for ISOPN, MVKN, MACRN, and PROPNN (Nguyen et al., 2015; Travis et al., 2016), with all other $\mathrm{RONO}_{2}$ deposition velocities scaled to that of ISOPN. Wet scavenging of gases is described in Amos et al. (2012) and has been modified here to use the same Henry's law coefficients as for dry deposition. Aerosol partitioning is described in Sect. 2.3 below.

\subsection{Monoterpene oxidation chemical mechanism}

Monoterpene chemistry is not included in the standard GEOS-Chem gas-phase chemical mechanism. Here we implement a monoterpene nitrate scheme developed by Browne et al. (2014) that was built on the RACM2 chemical mechanism (Goliff et al., 2013) and evaluated using aircraft observations over the Canadian boreal forest (Browne et al., 2014). Our implementation is summarized in Fig. 3 and described briefly below, with the full mechanism available in the Supplement (Tables S1-S3) and at http://wiki.seas.harvard.edu/ geos-chem/index.php/Monoterpene_nitrate_scheme. We include two lumped monoterpene tracers: API representing monoterpenes with one double bond ( $\alpha$-pinene, $\beta$-pinene, sabinene, and $\Delta$-3-carene) and LIM representing monoterpenes with two double bonds (limonene, myrcene, and ocimene). Combined, these species account for roughly $90 \%$ of all monoterpene emissions (Guenther et al., 2012), and we 

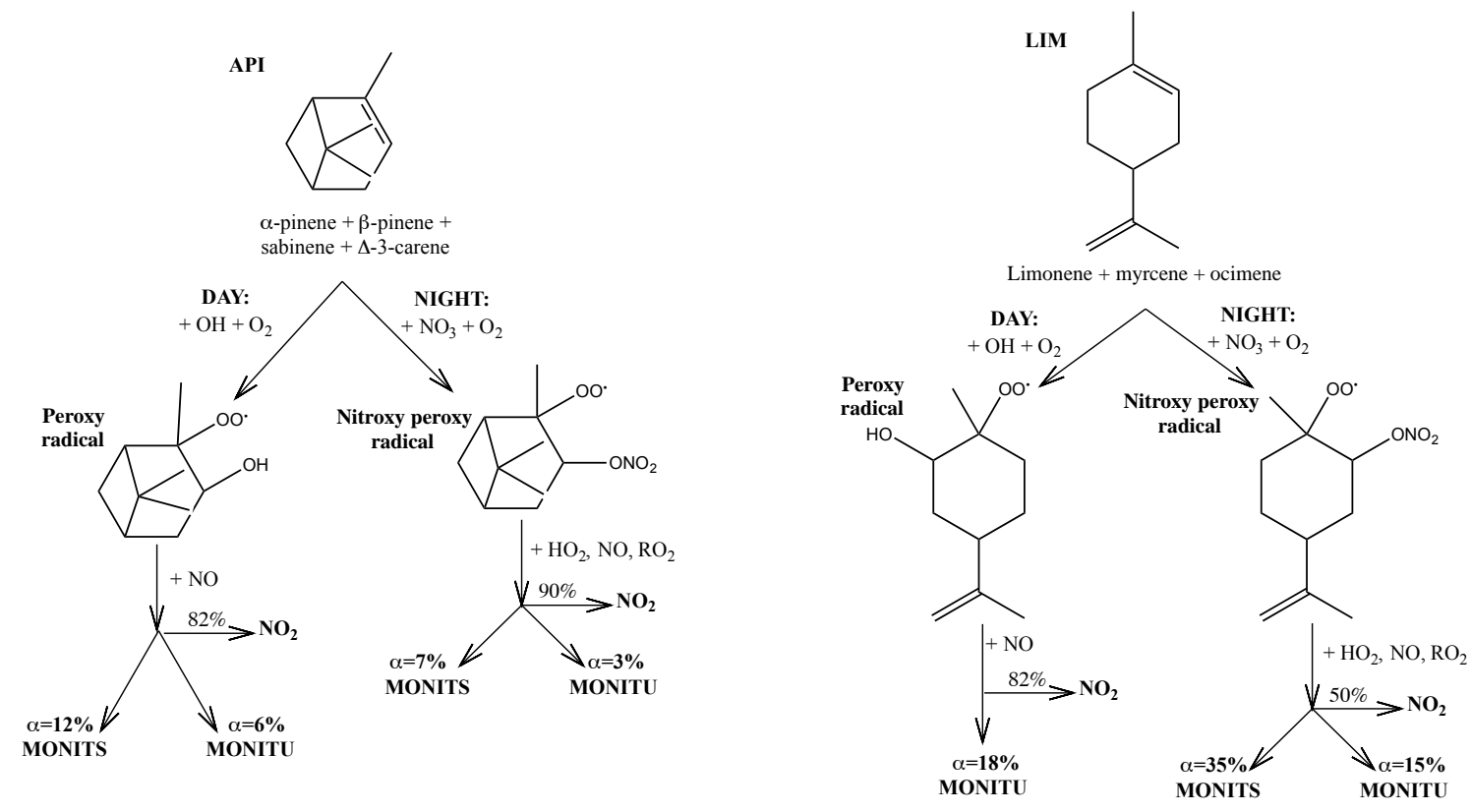

Figure 3. Simplified representation of the formation of monoterpene nitrates (MTN) from monoterpene oxidation as implemented in GEOSChem. For each lumped species, only one indicative form is shown.

neglect other terpenes here. During the day, LIM and API are oxidized by $\mathrm{OH}$ to form peroxy radicals. Subsequent reaction with NO forms first generation monoterpene nitrates with a yield of $18 \%$ (Nozière et al., 1999). These can be either saturated (MONITS) or unsaturated (MONITU), with precursordependent partitioning as shown in Fig. 3. For all subsequent discussion, we refer to their sum MONIT $=$ MONITU + MONITS.

At night, both LIM and API react with $\mathrm{NO}_{3}$ to form a nitrooxy peroxy radical that either decomposes to release $\mathrm{NO}_{2}$ or retains the nitrate functionality to form MONIT. The branching ratio between these two fates is $50 \%$ nitrateretaining for $\mathrm{LIM}+\mathrm{NO}_{3}$ (Fry et al., 2014) and $10 \%$ nitrateretaining for $\mathrm{API}+\mathrm{NO}_{3}$ (Browne et al., 2014). The $10 \%$ nitrate yield from $\mathrm{API}+\mathrm{NO}_{3}$ is on the low end of the observed range (Fry et al., 2014), so simulated pinene-derived MONIT should be considered a lower bound. In Browne et al. (2014), the API $+\mathrm{NO}_{3}$ reaction used the $\alpha$-pinene $+\mathrm{NO}_{3}$ rate constant from the Master Chemical Mechanism (MCMv3.2). We have updated this rate constant to $k_{\mathrm{API}}+\mathrm{NO}_{3}=8.33 \times$ $10^{-13} e^{490 / T}$, a rough average of the MCMv3.3 $\alpha$ - and $\beta$ pinene values, as API comprises both $\alpha$ - and $\beta$-pinenes (the dominant API components, present in roughly equal amounts during both SEAC ${ }^{4} \mathrm{RS}$ and SOAS). API and LIM also react with $\mathrm{O}_{3}$, but this reaction does not lead to $\mathrm{RONO}_{2}$ formation.

We do not distinguish between $\mathrm{OH}$-derived and $\mathrm{NO}_{3}$ derived MTN species. MONIT are subject to removal via wet and dry scavenging, aerosol uptake, photolysis, ozonolysis (MONITU only), and oxidation by OH. Here, we also add MONIT reaction with $\mathrm{NO}_{3}$ with the same rate constant as used for nighttime isoprene nitrates. The products of MONIT oxidation are currently unknown; here we follow Browne et al. (2014) and assume oxidation produces a second generation monoterpene nitrate (HONIT) that undergoes dry deposition, photolysis, and oxidative loss. In our simulation, HONIT is also removed via aerosol uptake (Sect. 2.3).

\subsection{Aerosol partitioning of $\mathrm{RONO}_{2}$}

Evidence from laboratory and field studies suggests aerosol uptake is a potentially significant loss pathway for gas-phase $\mathrm{RONO}_{2}$ (e.g., Day et al., 2010; Rollins et al., 2010; Darer et al., 2011; Fry et al., 2013, 2014). In particular, BVOC oxidation by $\mathrm{NO}_{3}$ radicals has been shown to result in high organic aerosol yields (Ng et al., 2008; Fry et al., 2009; Rollins et al., 2012). Recent work from SOAS highlighted the role of the monoterpenes $+\mathrm{NO}_{3}$ reaction, with an estimated 23$44 \%$ yield of organic nitrate aerosol (Ayres et al., 2015) that can explain roughly half of nighttime secondary organic aerosol production ( $\mathrm{Xu}$ et al., 2014). Isoprene $+\mathrm{NO}_{3}$ results in smaller but still significant yields; Xu et al. (2014) estimate that isoprene was responsible for $20 \%$ of nighttime $\mathrm{NO}_{3}$-derived organic aerosol observed during SOAS. Organic nitrate aerosol yields from daytime oxidation by $\mathrm{OH}$ are lower but non-negligible. At Bakersfield, for example, Rollins et al. (2013) found $21 \%$ of $\mathrm{RONO}_{2}$ partitioned to the aerosol phase during the day, and that these could explain $5 \%$ of the total daytime organic aerosol mass.

Aerosol partitioning of $\mathrm{RONO}_{2}$ has not previously been considered in GEOS-Chem. Here we add this process using a reactive uptake coefficient $(\gamma)$ parameterization. Our pa- 
rameterization was designed to provide a necessary sink for gas-phase $\mathrm{RONO}_{2}$ species (overestimated in earlier iterations of our model), and therefore makes a number of simplifying assumptions. In particular, we do not allow $\mathrm{pRONO}_{2}$ to repartition to the gas phase (likely to impact the more volatile isoprene-derived nitrates), and uptake coefficients are defined to fit the measurements of gas-phase species. More accurate simulation of organic nitrate aerosols would require additional updates that take into account vapor pressure differences between species (as done recently by Pye et al., 2015) and incorporate new findings from SOAS (Ayres et al., 2015; Lee et al., 2016). For our simulation, we apply reactive uptake to all BVOC-derived $\mathrm{RONO}_{2}$ except PROPNN and ETHLN, which lack hydroxyl groups and are therefore expected to be significantly less soluble. We assume an uptake coefficient of $\gamma=0.005$ for isoprene nitrates (from both daytime and nighttime chemistry) and $\gamma=0.01$ for all monoterpene nitrates (Table S4). Our isoprene nitrate uptake coefficient is in the middle of the range predicted by Marais et al. (2016) using a mechanistic formulation, and is a factor of 4 lower than the upper limit for ISOPN inferred by Wolfe et al. (2015) using SEAC ${ }^{4}$ RS flux measurements. Although simplified, we find this parameterization provides a reasonable fit to the SEAC ${ }^{4} \mathrm{RS}$ and SOAS observations of individual gas-phase $\mathrm{RONO}_{2}$ species measured by the CIT-ToF-CIMS and total $\mathrm{pRONO}_{2}$ measured by an aerosol mass spectrometer (AMS) (see Sects. 3 and 4).

After partitioning to the aerosol, laboratory experiments have shown that $\mathrm{pRONO}_{2}$ can hydrolyze to form alcohols and nitric acid via $\mathrm{pRONO}_{2}+\mathrm{H}_{2} \mathrm{O} \rightarrow \mathrm{ROH}+\mathrm{HNO}_{3}$. Some $\mathrm{pRONO}_{2}$ species hydrolyze rapidly under atmospherically relevant conditions, while others are stable against hydrolysis over timescales significantly longer than the organic aerosol lifetime against deposition (Darer et al., 2011; Hu et al., 2011; Liu et al., 2012; Jacobs et al., 2014; Rindelaub et al., 2015). Lifetimes against hydrolysis inferred from bulk aqueous and reaction chamber studies range widely from minutes (Darer et al., 2011; Rindelaub et al., 2015) to a few hours (Liu et al., 2012; Lee et al., 2016) to nearly a day (Jacobs et al., 2014). Here we apply a bulk lifetime against hydrolysis for the entire population of $\mathrm{pRONO}_{2}$ (similar to Pye et al., 2015). In other words, our implementation of aerosol partitioning involves a two-step process of (1) uptake of gas-phase $\mathrm{RONO}_{2}$ to form a simplified non-volatile $\mathrm{pRONO}_{2}$ species, with a rate determined by $\gamma$, followed by (2) hydrolysis of the simplified $\mathrm{pRONO}_{2}$ species to form $\mathrm{HNO}_{3}$, with a rate determined by the lifetime against hydrolysis. These steps are de-coupled, and we do not include any dependence of $\gamma$ on the hydrolysis rate (unlike the more detailed formulation of Marais et al., 2016). In subsequent sections, we compare the simplified $\mathrm{pRONO}_{2}$ formed as an intermediate during this process to total $\mathrm{pRONO}_{2}$ derived from observations. The assumption of a single hydrolysis lifetime overestimates the loss rate of non-tertiary nitrates (Darer et al., 2011; Hu et al., 2011) and may lead to model bias in total $\mathrm{pRONO}_{2}$, partic- ularly in the free troposphere where the longer-lived species would be more prevalent (see Sect. 4).

We assume here a bulk lifetime against hydrolysis of $1 \mathrm{~h}$, which we found in preliminary simulations to provide a better simulation of $\mathrm{pRONO}_{2}$ than longer lifetimes. Our $1 \mathrm{~h}$ bulk hydrolysis lifetime is shorter than the $2-4 \mathrm{~h}$ lifetime found in recent analysis of SOAS data and laboratory experiments (Boyd et al., 2015; Lee et al., 2016; Pye et al., 2015) - likely reflecting the simplifying assumptions of our uptake parameterization. In any case, the choice of hydrolysis lifetime does not affect the concentration of gas-phase $\mathrm{RONO}_{2}$ species (because $\mathrm{pRONO}_{2}$ cannot re-partition to the gas phase in the model), and we find this value provides a reasonable match to AMS measurements of total $\mathrm{pRONO}_{2}$ at the surface during SOAS and SEAC ${ }^{4} \mathrm{RS}$ (see Sects. 3 and 4). Impacts on $\mathrm{HNO}_{3}$ are minor: compared to a simulation without hydrolysis, our simulation with a $1 \mathrm{~h}$ lifetime against hydrolysis increased boundary layer $\mathrm{HNO}_{3}$ by $20 \mathrm{ppt}$, or $2.4 \%$.

\section{BVOCs and organic nitrates in the Southeast US}

We evaluate the updated GEOS-Chem simulation using Southeast US measurements of isoprene, monoterpenes, and a suite of oxidation products from two field campaigns in summer 2013. SEAC ${ }^{4} R S$ was a NASA aircraft campaign that took place in AugustSeptember 2013 (Toon et al., 2016). All observations discussed in this work were taken onboard the NASA DC8 (data doi:10.5067/Aircraft/SEAC4RS/Aerosol-TraceGasCloud), which was based in Houston, Texas, with an $\sim 8 \mathrm{~h}$ flight range. SOAS was a ground-based campaign that took place in June-July 2013 at the Centreville monitoring site near Brent, Alabama $\left(32.903^{\circ} \mathrm{N}, 87.250^{\circ} \mathrm{W}\right)$.

\subsection{Isoprene and monoterpenes}

Understanding BVOC sources and chemistry was a primary goal of SEAC ${ }^{4} \mathrm{RS}$, resulting in a large number of boundary layer flights over regions of enhanced biogenic emissions (Kim et al., 2015). Isoprene and monoterpene distributions in Southeast US surface air $\left(80-94.5^{\circ} \mathrm{W}, 29.5-40^{\circ} \mathrm{N}\right.$, and below $1 \mathrm{~km}$ ) measured by PTR-MS are shown in Fig. 4, and their campaign-median vertical profiles are shown in Fig. 5b, c. Whole air sampler (WAS) measurements of isoprene and $\alpha$-pinene $+\beta$-pinene (Fig. S1 in the Supplement) are similar, but with more limited sampling than the PTR-MS. All observations have been averaged to the spatial and temporal resolution of the model.

The SOAS site is located at the edge of a mixed coniferous and deciduous forest (Nguyen et al., 2015). SOAS observations of isoprene and monoterpenes, measured by PTR-ToFMS and averaged to hourly mean values, are shown in Fig. 6. Both species display a clear diurnal cycle with peak isoprene during day, reflecting the light- and temperature-dependent 
DC-8 OBSERVATIONS
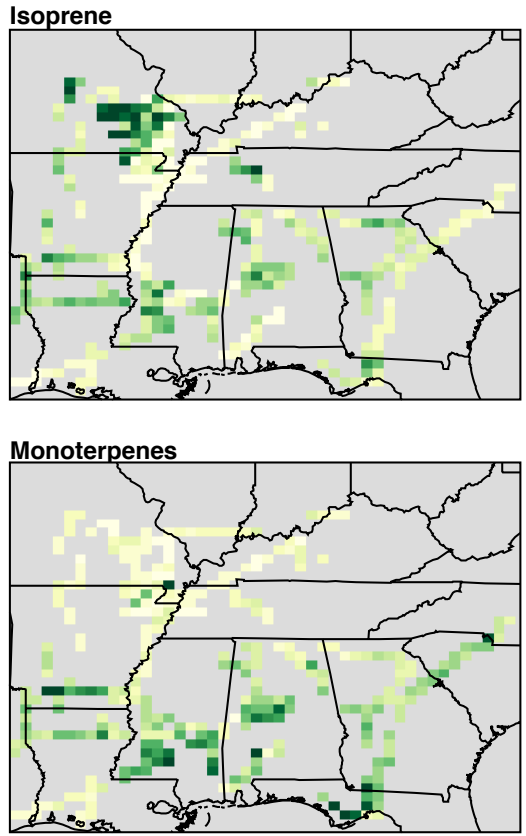

GEOS-CHEM
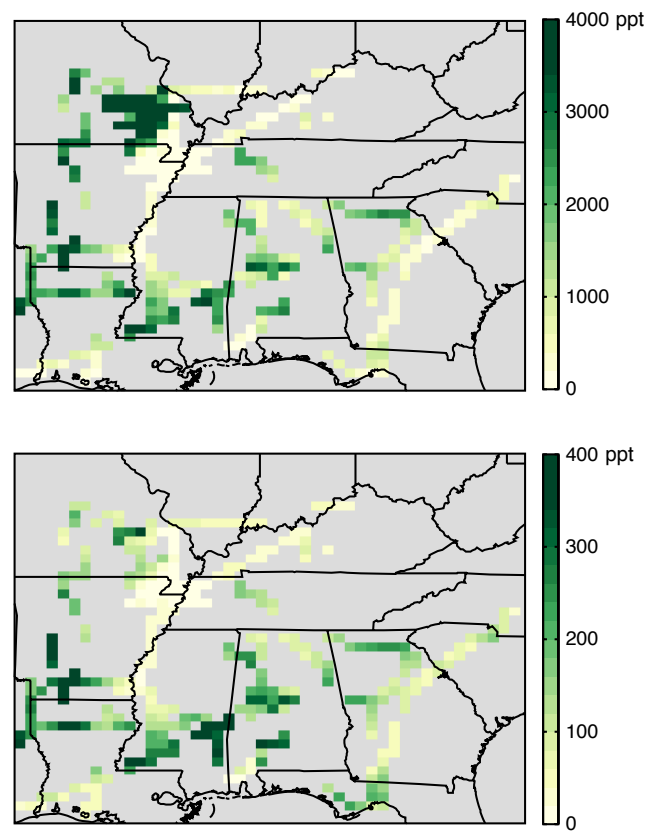

Figure 4. Observed (left) and simulated (right) mixing ratios of isoprene and monoterpenes below $1 \mathrm{~km}$ during the SEAC ${ }^{4} \mathrm{RS}$ aircraft campaign (12 August-23 September 2013). The GEOS-Chem model has been sampled along the aircraft flight tracks, and the observations binned to the spatial and temporal resolution of the model. The normalized mean bias of the simulation relative to the PTR-MS measurements in the lowest $500 \mathrm{~m}$ is $+34 \%$ for isoprene and $+3 \%$ for monoterpenes.

source, and peak monoterpenes at night. For monoterpenes, the figure also shows the sum of $\alpha$-pinene $+\beta$-pinene as measured by 2D-GC-FID, which indicates that these are the dominant monoterpenes.

Figures 4, 5, and 6 compare observed BVOCs from both campaigns to the GEOS-Chem simulation, sampled to match the observations. Similar figures for $\mathrm{NO}_{x}$ can be found in Travis et al. (2016) and in Fig. S2. Model bias relative to observations is quantified using the normalized mean bias $\mathrm{NMB}=100 \% \times\left[\sum_{i}\left(M_{i}-O_{i}\right) / \sum_{i}\left(O_{i}\right)\right]$, where $O_{i}$ and $M_{i}$ are the observed and modeled values and the summation is over all hours (SOAS) or unique grid box-time step combinations along the flight tracks (SEAC ${ }^{4} \mathrm{RS}$ ). BVOC emissions are from MEGANv2.1 (Guenther et al., 2012) and have been decreased by $15 \%$ for isoprene and doubled for monoterpenes to better match aircraft (isoprene, monoterpene) and satellite (formaldehyde) observations (Kim et al., 2015; Zhu et al., 2016). With these scalings applied, simulated surface isoprene and monoterpenes overestimate somewhat the SEAC ${ }^{4}$ RS data (Fig. 4, mainly due to a few simulated highBVOC events), but the medians are well within the observed variability (Fig. 5). Model high bias above $500 \mathrm{~m}$ is likely caused by excessive vertical mixing through the simulated boundary layer (Travis et al., 2016). Relative to the SOAS data, simulated monoterpenes are biased low by a factor of 2 , while isoprene falls within the interquartile range of the measurements. The opposite sign of the SOAS monoterpene bias relative to the more spatially representative SEAC ${ }^{4} \mathrm{RS}$ data suggests a low bias in MEGANv2.1 monoterpene emissions that is unique to the Centreville grid box; errors in vertical mixing may also contribute. For isoprene, the model reproduces both the observed nighttime decline and the subsequent morning growth with a small delay $(\sim 1 \mathrm{~h})$.

The observed declines in isoprene at night (Fig. 6) and above the boundary layer (Fig. 5) reflect its short lifetime against oxidation. We find in the model that $\mathrm{OH}$ oxidation accounts for $90 \%$ of isoprene loss (Marais et al., 2016), but only $65 \%$ of monoterpene loss (with $\mathrm{NO}_{3}$ responsible for most of the rest). For isoprene, the subsequent fate of the peroxy radicals $\left(\mathrm{ISOPO}_{2}\right)$ has been evaluated in detail by Travis et al. (2016), who also present an in-depth analysis of the $\mathrm{NO}_{x}$ budget and impacts on ozone. They show that on average $56 \%$ of $\mathrm{ISOPO}_{2}$ reaction during $\mathrm{SEAC}^{4} \mathrm{RS}$ is with NO, and that there is large spatial variability in this term that is accurately reproduced by the high-resolution GEOS-Chem simulation. Here we focus exclusively on this pathway and the resultant formation of $\mathrm{RONO}_{2}$ from both isoprene and monoterpenes.

\subsection{First generation $\mathrm{RONO}_{2}$}

Observed near-surface mixing ratios of first generation isoprene nitrates (ISOPN) during SEAC ${ }^{4} \mathrm{RS}$ are shown in Fig. 7 
Table 1. Gas-phase organic nitrates in GEOS-Chem: formation and loss pathways and lifetimes. ${ }^{\mathrm{a}}$

\begin{tabular}{|c|c|c|c|c|}
\hline Species & Model name & Principal formation pathways ${ }^{b}$ & Removal processes $^{\mathrm{c}}$ & Lifetime $(\mathrm{h})^{\mathrm{d}}$ \\
\hline $\begin{array}{l}\beta \text {-hydroxy } \\
\text { Isoprene nitrate }\end{array}$ & ISOPNB & $\mathrm{ISOP}+\mathrm{OH}$ & $\begin{array}{l}\text { Aerosol hydrolysis } \\
\text { Deposition } \\
\text { Oxidation } \\
\text { Photolysis }\end{array}$ & 1.8 \\
\hline $\begin{array}{l}\delta \text {-hydroxy } \\
\text { Isoprene nitrate }\end{array}$ & ISOPND & $\mathrm{ISOP}+\mathrm{OH}$ & $\begin{array}{l}\text { Deposition } \\
\text { Oxidation } \\
\text { Aerosol hydrolysis } \\
\text { Photolysis }\end{array}$ & 4.0 \\
\hline $\mathrm{C}_{5}$ nitrooxy carbonyl & ISN1 & $\mathrm{ISOP}+\mathrm{NO}_{3}$ & $\begin{array}{l}\text { Deposition } \\
\text { Photolysis } \\
\text { Oxidation } \\
\text { Aerosol hydrolysis }\end{array}$ & 0.29 \\
\hline $\begin{array}{l}\mathrm{C}_{5} \text { nitrooxy } \\
\text { hydroperoxide }\end{array}$ & INPN & $\mathrm{ISOP}+\mathrm{NO}_{3}$ & NA & NA \\
\hline Methyl vinyl ketone nitrate & MVKN & $\mathrm{ISOPNB}+\mathrm{OH}$ & $\begin{array}{l}\text { Deposition } \\
\text { Aerosol hydrolysis } \\
\text { Photolysis } \\
\text { Oxidation }\end{array}$ & 3.1 \\
\hline Methacrolein nitrate & MACRN & $\mathrm{ISOPNB}+\mathrm{OH}$ & $\begin{array}{l}\text { Photolysis } \\
\text { Deposition } \\
\text { Aerosol hydrolysis } \\
\text { Oxidation }\end{array}$ & 1.5 \\
\hline Propanone nitrate & PROPNN & $\begin{array}{l}\text { ISOPND + OH } \\
\text { ISN } 1+\mathrm{NO}_{3}\end{array}$ & $\begin{array}{l}\text { Deposition } \\
\text { Photolysis } \\
\text { Oxidation }\end{array}$ & 3.3 \\
\hline Ethanal nitrate & ETHLN & ISOPND + OH & $\begin{array}{l}\text { Deposition } \\
\text { Photolysis } \\
\text { Oxidation }\end{array}$ & 1.5 \\
\hline $\mathrm{C}_{5}$ dihydroxy dinitrate & DHDN & $\begin{array}{l}\text { ISOPND + OH } \\
\text { ISOPND + OH }\end{array}$ & $\begin{array}{l}\text { Aerosol hydrolysis } \\
\text { Deposition }\end{array}$ & 4.6 \\
\hline $\begin{array}{l}\text { Saturated first generation } \\
\text { Monoterpene nitrate }\end{array}$ & MONITS & $\begin{array}{l}\mathrm{API}+\mathrm{OH} \\
\mathrm{API}+\mathrm{NO}_{3} \\
\mathrm{LIM}+\mathrm{NO}_{3}\end{array}$ & $\begin{array}{l}\text { Deposition } \\
\text { Aerosol hydrolysis } \\
\text { Oxidation } \\
\text { Photolysis }\end{array}$ & 1.8 \\
\hline $\begin{array}{l}\text { Unsaturated first generation } \\
\text { Monoterpene nitrate }\end{array}$ & MONITU & $\begin{array}{l}\mathrm{API}+\mathrm{OH} \\
\mathrm{API}+\mathrm{NO}_{3} \\
\mathrm{LIM}+\mathrm{OH} \\
\mathrm{LIM}+\mathrm{NO}_{3}\end{array}$ & $\begin{array}{l}\text { Oxidation } \\
\text { Deposition } \\
\text { Aerosol hydrolysis } \\
\text { Photolysis }\end{array}$ & 0.85 \\
\hline $\begin{array}{l}\text { Second generation } \\
\text { Monoterpene nitrate }\end{array}$ & HONIT & $\begin{array}{l}\text { MONITU + OH } \\
\text { MONITS + OH }\end{array}$ & $\begin{array}{l}\text { Aerosol hydrolysis } \\
\text { Deposition } \\
\text { Photolysis } \\
\text { Oxidation }\end{array}$ & 1.7 \\
\hline
\end{tabular}

${ }^{\mathrm{a}}$ Model results are averaged over Southeast US surface air sampled along the SEAC ${ }^{4} \mathrm{RS}$ flight tracks.

${ }^{b}$ Primary precursor(s) and associated oxidant(s). The related peroxy radicals and their oxidants can be seen in Figs. 2 and 3.

${ }^{\mathrm{c}}$ Removal processes for each species are ordered by their contribution to total loss during SEAC ${ }^{4} \mathrm{RS}$. Losses due to oxidation, photolysis, and aerosol uptake are calculated along the SEAC ${ }^{4} \mathrm{RS}$ flight tracks. Deposition includes both dry and wet scavenging and is calculated from regional means over all Southeast US grid boxes. Wet deposition in the model is calculated for lumped species ISOPNB+ISOPND, MVKN + MACRN, and MONITU+MONITS and individually for all others. For this table, we assume partitioning of $90 \%$ ISOPNB (10\% ISOPND) based on the initial formation yields and a 50 : 50 split for the other lumped species. Wet scavenging is only a small contribution to total $\mathrm{RONO}_{2}$ deposition, and this assumption has minimal impact on these values.

${ }^{\mathrm{d}}$ Lifetimes are the combined lifetimes against deposition as calculated over all grid boxes and against oxidation, photolysis, and aerosol hydrolysis as calculated along the flight tracks, with further details in note $c$. These are representative of daytime conditions only, as determined by the timing of the SEAC ${ }^{4}$ RS flights.

e INPN is not treated as a transported species, so diagnostics needed to calculate removal rates and lifetime are not available. 

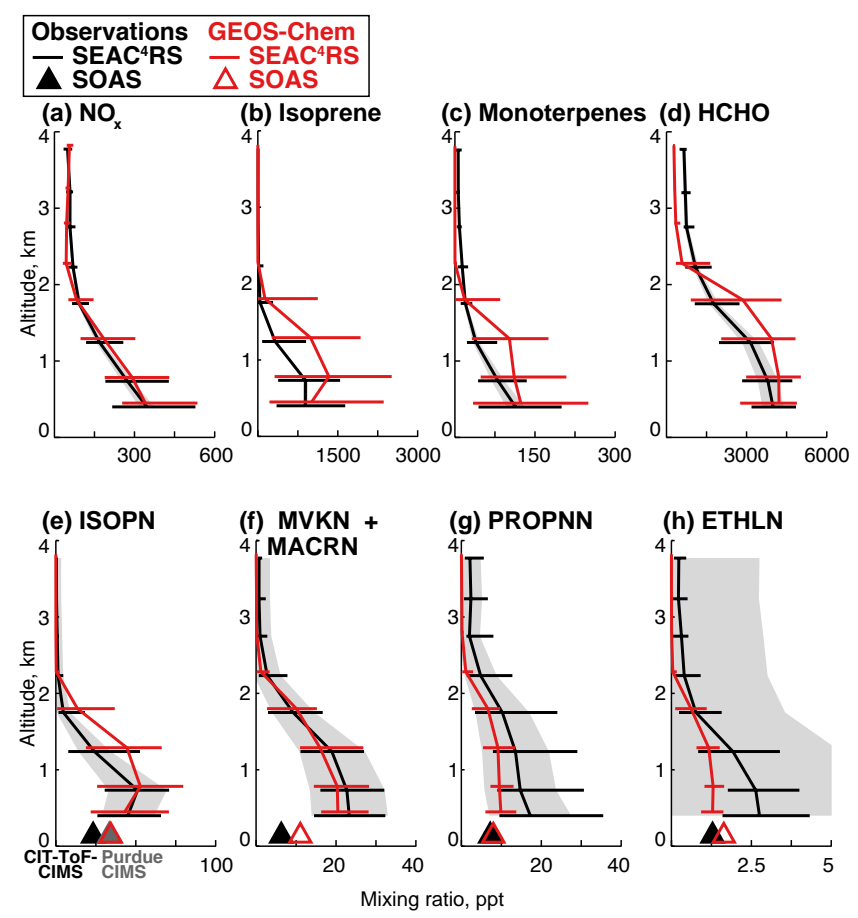

Figure 5. Observed (black) and modeled (red) median $0-4 \mathrm{~km}$ profiles of $\mathrm{NO}_{x}$, biogenic VOCs, and oxidation products over the Southeast US $\left(80-94.5^{\circ} \mathrm{W}, 29.5-40^{\circ} \mathrm{N}\right)$ during SEAC ${ }^{4} \mathrm{RS}$. Data are binned in $500 \mathrm{~m}$ increments, and horizontal lines indicate the interquartile range within each bin. Gray shading represents the measurement uncertainty. The model has been sampled in the same manner as the observations, as described in the text. For organic nitrates (e-h), SOAS campaign median surface values are shown as triangles. For ISOPN (e), the gray triangle represents the Purdue CIMS and the black triangle the CIT-ToF-CIMS.

and are generally well represented by GEOS-Chem $(r=$ $0.61 ; \mathrm{NMB}=-0.6 \%)$. ISOPN vertical profiles in Fig. 5e indicate a rapid decline from the boundary layer to the free troposphere, reflecting the short atmospheric lifetime $(2-4 \mathrm{~h}$ in our simulation; Table 1). Comparing the lowest altitude SEAC ${ }^{4} \mathrm{RS}$ observations to the SOAS median from the CITToF-CIMS (black triangle) indicates an apparent vertical gradient from the surface to $\sim 500 \mathrm{~m}$. This could be caused by spatial variability between the campaigns, or could reflect rapid dry deposition of ISOPN with limited vertical mixing. GEOS-Chem does not simulate this SOAS-SEAC ${ }^{4}$ RS difference, possibly due to overly strong vertical mixing through the modeled boundary layer as identified by Travis et al. (2016) from model comparison to SEACIONS ozonesonde observations.

During SOAS, ISOPN was measured simultaneously by the CIT-ToF-CIMS (Crounse et al., 2006; Nguyen et al., 2015) and the Purdue CIMS (Xiong et al., 2015), and Fig. 6 shows the diurnal cycles from both. Median ISOPN from the Purdue CIMS is a factor of 2 higher than that from the CIT-ToF-CIMS during daylight hours, with the most significant differences in mid-late morning. In both data sets, ISOPN peaks around 10:00 LT, is elevated until early evening, and declines to a pre-dawn minimum. Simulated ISOPN from GEOS-Chem is in good agreement with the Purdue CIMS measurements except in the afternoon, when modeled ISOPN shows a broad peak (rather than the observed decline) coincident with simulated peak isoprene (Fig. 6). After $\sim$ 19:00 LT, the model captures the observed timing of the nighttime ISOPN decline seen in both data sets, as well as the rapid morning growth seen in the Purdue CIMS measurements.

As described in Sect. 2.1, there is considerable uncertainty in the ISOPN yield. We find here that a $9 \%$ yield provides the best simulation of the ensemble of SEAC ${ }^{4} \mathrm{RS}$ and SOAS observations, given experimental constraints on oxidative loss rates (Lee et al., 2014) and dry deposition fluxes (Nguyen et al., 2015). Using model sensitivity studies, we found that applying a lower yield of $7 \%$ improved the agreement with the CIT-ToF-CIMS during SOAS, but worsened agreement with the other data sets and is inconsistent with the yields from laboratory experiments (Teng et al., 2016). We also tested a higher yield of $12 \%$, and found the model overestimated observed SEAC ${ }^{4}$ RS and SOAS ISOPN (from both instruments) unless we invoked much larger aerosol uptake and/or added another ISOPN sink. ISOPN sinks (especially aerosol uptake) remain poorly constrained, and the uncertain parameter space describing these processes likely contains multiple solutions that fit the observations equally well (i.e., a higher yield could be accommodated by faster ISOPN loss to aerosol).

Our finding that GEOS-Chem can reproduce the Purdue CIMS ISOPN observations using a 9\% ISOPN yield is consistent with the box model of Xiong et al. (2015). The chemical mechanisms used in both studies are similar. In both simulations, modeled ISOPN was overestimated unless an extra sink was included (also consistent with Wolfe et al., 2015, who inferred a missing sink based on $\operatorname{SEAC}^{4}$ RS flux measurements). While we assumed this sink was due to aerosol uptake, Xiong et al. (2015) invoked enhanced ISOPN photolysis. They argued that models typically underestimate the ISOPN absorption cross section by not taking into account the combined influence of the double bond and hydroxyl group in the ISOPN structure (Fig. 2). Xiong et al. (2015) were better able to reproduce the observed ISOPN morning peak and afternoon decline when they increased the MCMv3.2 photolysis rate constant by a factor of 5 . Including both faster ISOPN photolysis and uptake to the aerosol phase could be a means to accommodate a higher initial ISOPN yield, such as the $12-14 \%$ yield inferred from laboratory experiments with the CIT-ToF-CIMS (Teng et al., 2016), although both sinks remain unverified. The nature of the sink has implications for $\mathrm{NO}_{x}$ recycling from isoprene nitrates (photolysis recycles $\mathrm{NO}_{x}$, while uptake removes it), and this remains a source of uncertainty in our estimates of the impacts of $\mathrm{RONO}_{2}$ on the $\mathrm{NO}_{x}$ budget. 

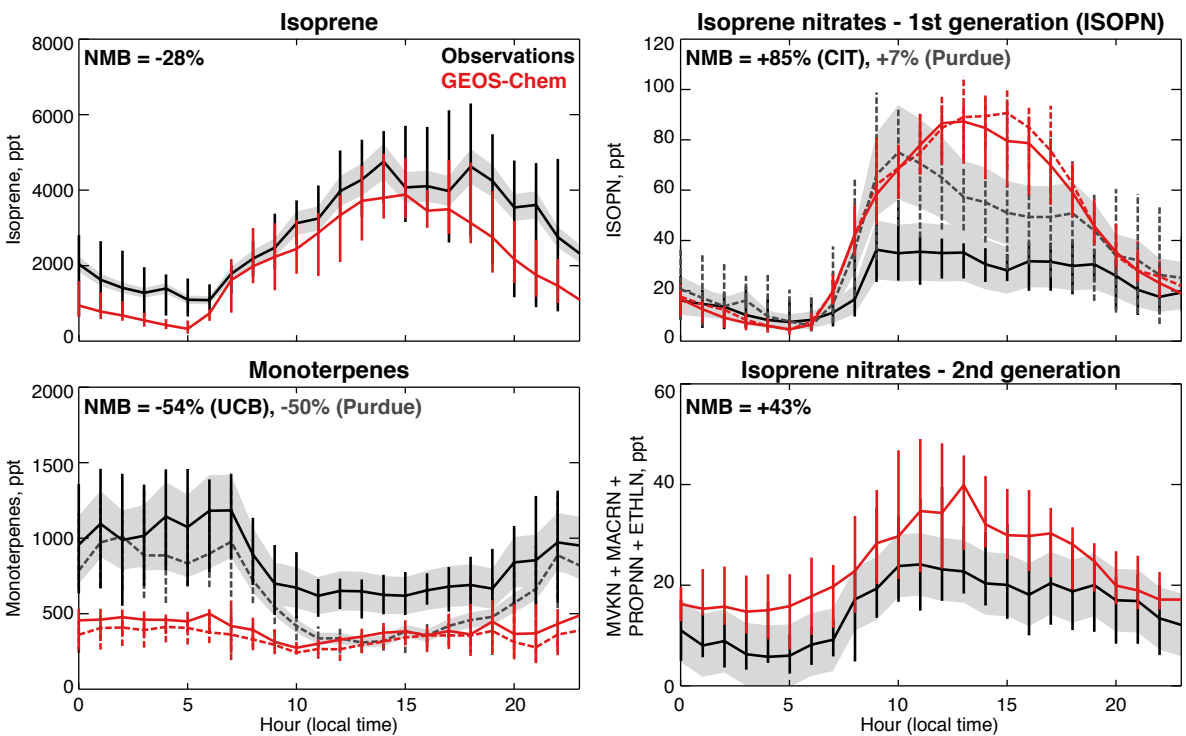

Figure 6. Observed (black, gray) and simulated (red) median diurnal cycles of isoprene, monoterpenes, first generation isoprene nitrates (ISOPN), and second generation isoprene nitrates (MVKN+MACRN+PROPNN+ETHLN) at Centreville during the 2013 SOAS campaign. Gray shading represents the measurement uncertainty, vertical bars show the interquartile range of the hourly data, and the normalized mean bias (NMB) of the simulation is given inset. The model has been sampled in the Centreville grid box only for hours with available data during 16 June-11 July for isoprene and monoterpenes from the UC Berkeley PTR-ToF-MS (solid black), 13 June-15 July for $\alpha$-pinene $+\beta$-pinene from the Purdue 2D-GF-FID (dashed gray), 1 June-11 July for ISOPN from the Purdue CIMS (dashed gray), and 1 June-4 July for ISOPN and second generation isoprene nitrates from the CIT-ToF-CIMS (solid black). For ISOPN and monoterpenes, differences in data availability between the two measurements result in slightly different model values (solid/dashed red lines).

DC-8 OBSERVATIONS

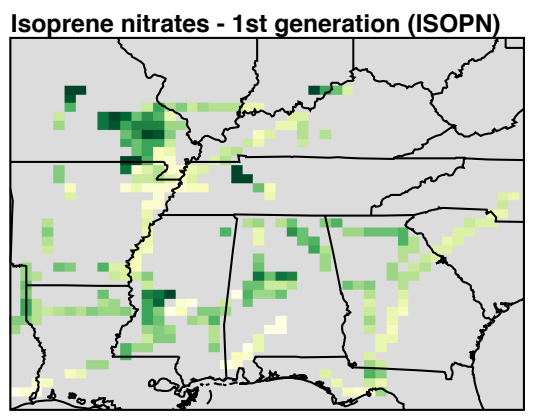

\section{GEOS-CHEM}
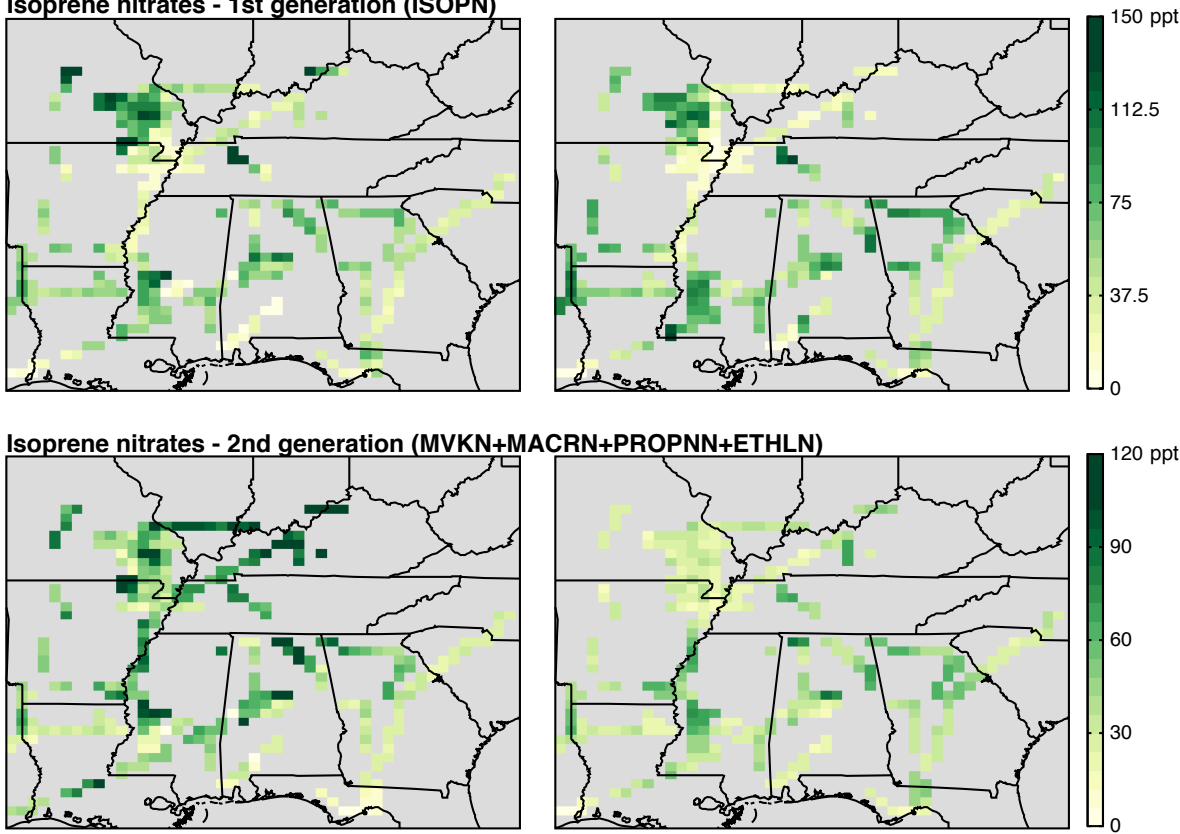

Figure 7. Observed (left) and simulated (right) mixing ratios of isoprene nitrates below $1 \mathrm{~km}$ during SEAC ${ }^{4} \mathrm{RS}$, separated into first generation (ISOPN) and second generation (MVKN+MACRN+PROPNN+ETHLN) species. The GEOS-Chem simulation has been sampled along the aircraft flight tracks, and the observations binned to the spatial and temporal resolution of the model, as described in the text. The normalized mean bias of the simulation relative to the measurements in the lowest $500 \mathrm{~m}$ is $-0.6 \%$ for ISOPN and $-35 \%$ for second generation isoprene nitrates. 
Even more uncertain than ISOPN are the first generation monoterpene nitrates (MONIT). MONIT in GEOS-Chem is a lumped species that represents the sum of monoterpene nitrates from both daytime $\mathrm{OH}$-initiated and nighttime $\mathrm{NO}_{3}$ initiated oxidation (Sect. 2.2). The nighttime oxidation cascade involves a diversity of reactants (including $\mathrm{NO}, \mathrm{HO}_{2}$, $\mathrm{NO}_{3}$, and other peroxy radicals) and produces a diversity of monoterpene nitrate species (Lee et al., 2016) that we do not distinguish here. In the model, most MONIT is produced from the $\mathrm{NO}_{3}$-initiated chemistry, resulting in mean MONIT concentrations of 30-60 ppt at night and $\sim 10-20$ ppt during the day.

During SOAS, two monoterpene nitrates were measured by the CIT-ToF-CIMS: $\mathrm{C}_{10} \mathrm{H}_{17} \mathrm{NO}_{4}$ and $\mathrm{C}_{10} \mathrm{H}_{17} \mathrm{NO}_{5}$. We find that simulated MONIT shows the same diurnal pattern as the sum of the two measured species (with peak concentrations at night) but is a factor of 2-3 higher (Fig. S3). Pye et al. (2015) similarly found simulated MONIT was a factor of 7 higher than observations using a version of the CMAQ model with explicit MONIT chemistry. The higher modeled values in both studies presumably reflect inclusion in modeled MONIT of many species that were not measured by CITToF-CIMS (including several identified during SOAS by Lee et al., 2016), as well as biases in the model mechanisms (most of the rate constants and products have not been measured). $\mathrm{NO}_{3}$-initiated monoterpene oxidation is particularly uncertain and is likely too strong in GEOS-Chem, as indicated by large nighttime MONIT overestimates (Fig. S3) combined with monoterpene underestimates (Fig. 6). Simulated nighttime peak values of $\mathrm{NO}_{3}$-derived isoprene nitrates (ISN1) during SOAS are also up to a factor of 2 higher than the observations reported by Schwantes et al. (2015). This suggests that model biases in nighttime PBL heights and associated vertical mixing may also contribute to simulated nighttime overestimates for some $\mathrm{RONO}_{2}$ species.

\subsection{Second generation $\mathrm{RONO}_{2}$ and $\mathrm{pRONO}_{2}$}

First generation ISOPN and MONIT undergo further oxidation to form a suite of second generation $\mathrm{RONO}_{2}$ species that retain the nitrate functionality (Figs. 2 and 3). Four of these species (MVKN, MACRN, PROPNN, and ETHLN) were measured by the CIT-ToF-CIMS, with vertical profiles shown in Fig. $5 \mathrm{f}-\mathrm{h}$ and spatial distribution shown in Fig. 7. The model provides a good simulation of SEAC ${ }^{4} \mathrm{RS}$ MVKN+MACRN but underestimates the variability of PROPNN and ETHLN. In contrast, all three species show positive mean model biases relative to the SOAS surface observations. The model tends to overestimate PROPNN and ETHLN at night but underestimate them during the day (Fig. S3), reflecting the assumption in our mechanism that PROPNN is produced at night during $\mathrm{NO}_{3}$-initiated isoprene oxidation. In reality, the nighttime chemistry produces INs that only photo-oxidize to PROPNN after sunrise (Schwantes et al., 2015). This missing delay between nighttime $\mathrm{NO}_{3}$ ad- dition and subsequent daytime photo-oxidation likely also explains the model bias relative to the SEAC ${ }^{4} \mathrm{RS}$ observations, which mostly took place during daytime. Additional simplifications in the $\mathrm{NO}_{3}$-initiated chemistry could also contribute to the biases, and preliminary simulations conducted with the AM3 model show that including more details of this chemistry improves model ability to match observed PROPNN (Li et al., 2016). Some of the bias may also be due to error in the assumed distribution between $\beta$ - and $\delta$-channel $\mathrm{OH}$-initiated oxidation, as both PROPNN and ETHLN are produced by the latter channel only.

The full time series of first and second generation INs measured at Centreville during SOAS are shown in Fig. 8. We also include the time series of observed particulate $\mathrm{RONO}_{2}$ $\left(\mathrm{pRONO}_{2}\right)$ estimated from AMS measurements (Fry et al., 2013; Ayres et al., 2015; Lee et al., 2016; Day et al., 2016) and of $\Sigma$ ANs, the sum of all $\mathrm{RONO}_{2}$ species (including $\mathrm{pRONO}_{2}$ ) as measured by thermal dissociation laser-induced fluorescence (TD-LIF; Day et al., 2002). Despite the biases identified above, the simulation captures the temporal variability in gas-phase, particulate, and total $\mathrm{RONO}_{2}$ observed over the 6 -week campaign, with correlation coefficients of $r \sim 0.6-0.7$. Low observed and modeled values for all species in early July (days 185-189) indicate suppressed BVOC emissions caused by low temperatures (Marais et al., 2016). The model underestimates both $\mathrm{pRONO}_{2}$ and $\Sigma \mathrm{ANs}$ at night (Fig. S3), suggesting that hydrolysis of particulate monoterpene nitrates should be slower than assumed here (Sect. 2.3). Afternoon overestimates of $\mathrm{pRONO}_{2}$ relative to the AMS observations (Fig. S3) are coincident with the peak in isoprene nitrates (Fig. 6), suggesting overly strong partitioning to the aerosol phase likely due to our assumption of irreversibility (Sect. 2.3).

\section{$3.4 \mathrm{RONO}_{2}-\mathrm{HCHO}$ relationship}

The relationship between organic nitrates and formaldehyde (HCHO), a high-yield product of the $\mathrm{ISOPO}_{2}+\mathrm{NO}$ reaction, provides an additional test of the model chemistry and in particular the IN yield. Daytime isoprene oxidation in the presence of $\mathrm{NO}_{x}$ co-produces $\mathrm{HCHO}$ and INs, resulting in an expected strong correlation between these species (Perring et al., 2009a). When INs dominate total $\mathrm{RONO}_{2}$, the correlation should also be strong between $\mathrm{HCHO}$ and $\Sigma$ ANs, and this relationship has previously been used to constrain the IN yield when IN measurements were not available. For example, $\mathrm{HCHO}$ and $\Sigma \mathrm{ANs}$ measurements from the 2004 ICARTT aircraft campaign showed moderate correlation with $r \sim 0.4-0.6$ (Perring et al., 2009a; Mao et al., 2013). However, linking the $\mathrm{HCHO}-\Sigma \mathrm{ANs}$ correlation to the IN yield is complicated by the contribution to $\Sigma$ ANs from other $\mathrm{RONO}_{2}$ sources (e.g., monoterpene nitrates, anthropogenic nitrates). During $\mathrm{SEAC}^{4} \mathrm{RS}$, a better constraint can be obtained directly from the $\mathrm{HCHO}-\mathrm{IN}$ relationship. Figure 9 shows the correlation between $\mathrm{HCHO}$ and the sum of 

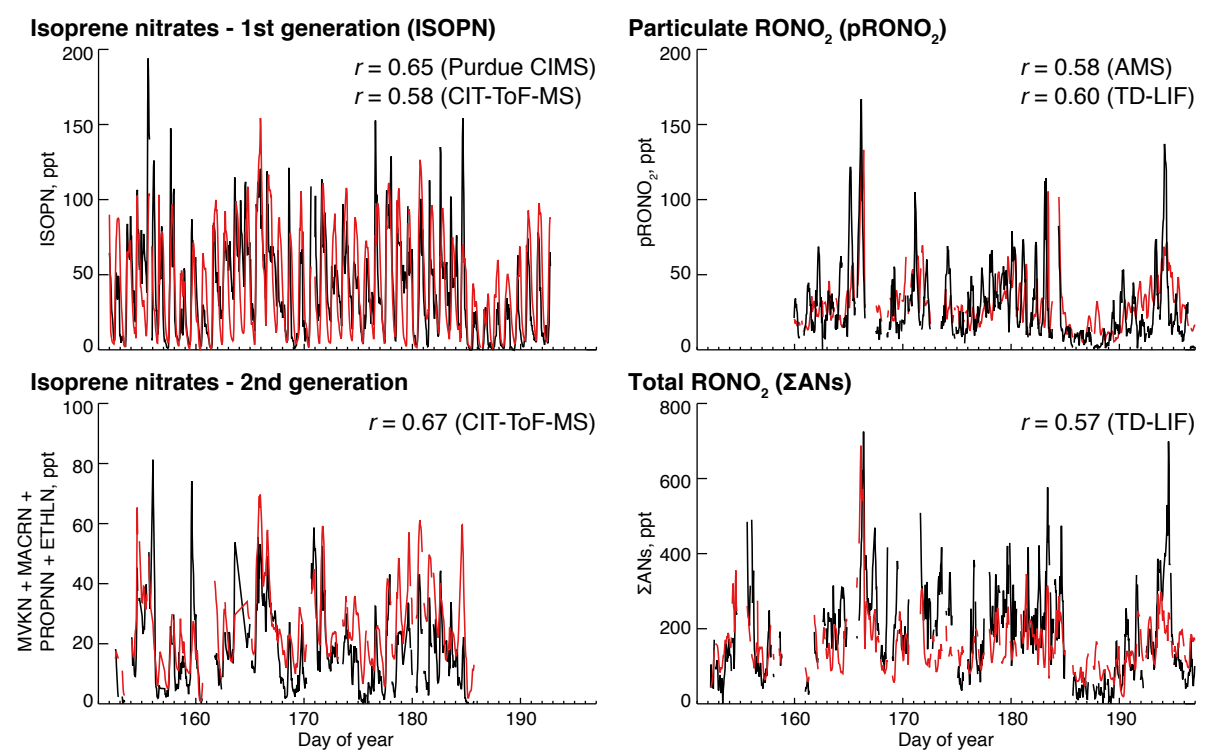

Figure 8. Time series of observed (black) and simulated (red) hourly mean $\mathrm{RONO}_{2}$ at Centreville during the $2013 \mathrm{SOAS}$ campaign for first generation isoprene nitrates (ISOPN, from the Purdue CIMS), second generation isoprene nitrates (MVKN+MACRN+PROPNN+ETHLN from the CIT-ToF-CIMS), particulate $\mathrm{RONO}_{2}\left(\mathrm{pRONO}_{2}\right.$, from the AMS) and total alkyl and multifunctional nitrates ( $\Sigma$ ANs, from the TD-LIF). The model has been sampled in the Centreville grid box only for hours with available data from each instrument. The modelobservation correlation coefficient $(r)$ for each species is given inset both for the measurement shown and (where available) for additional measurement of the same species (with time series shown in Fig. S4).

ISOPN, MVKN, and MACRN (we exclude PROPNN and ETHLN to avoid the biases identified previously). The figure shows the observed slope of 0.027 (ppt IN) (ppt HCHO) $)^{-1}$ is reproduced by the model but with more scatter in the simulation $(r \sim 0.5)$ than in the observations $(r \sim 0.7)$. The similarity of the observed and simulated relationships in Fig. 9 lends confidence to the IN mechanism used here, at least for the $\beta$-peroxy channel.

\section{Total alkyl and multifunctional nitrates ( $\Sigma$ ANs)}

\subsection{Speciated vs. total $\mathrm{RONO}_{2}$}

SEAC ${ }^{4} \mathrm{RS}$ represents one of the first airborne campaigns to make measurements of individual BVOC-derived $\mathrm{RONO}_{2}$ species. Without these speciated measurements, previous model evaluations of isoprene nitrate chemistry have relied on TD-LIF observations of $\Sigma$ ANs (total $\mathrm{RONO}_{2}$ ), with the assumption that gas-phase INs account for the majority of $\Sigma$ ANs (Horowitz et al., 2007; Perring et al., 2009a; Mao et al., 2013; Xie et al., 2013). Figure 10a compares the TD-LIF $\Sigma$ ANs measurement (solid line) to the sum of explicitly measured gas-phase $\mathrm{RONO}_{2}$ species and total $\mathrm{pRONO}_{2}$ (dashed line, combined CIT-ToF-CIMS, WAS, and AMS measurements) during SEAC ${ }^{4} \mathrm{RS}$. The figure shows a large gap between measured $\Sigma$ ANs and the total of speciated $\mathrm{RONO}_{2}$ (including both gas-phase and aerosol contributions $)$, especially near the surface $(\Sigma \mathrm{ANs}=409 \mathrm{ppt}$, total

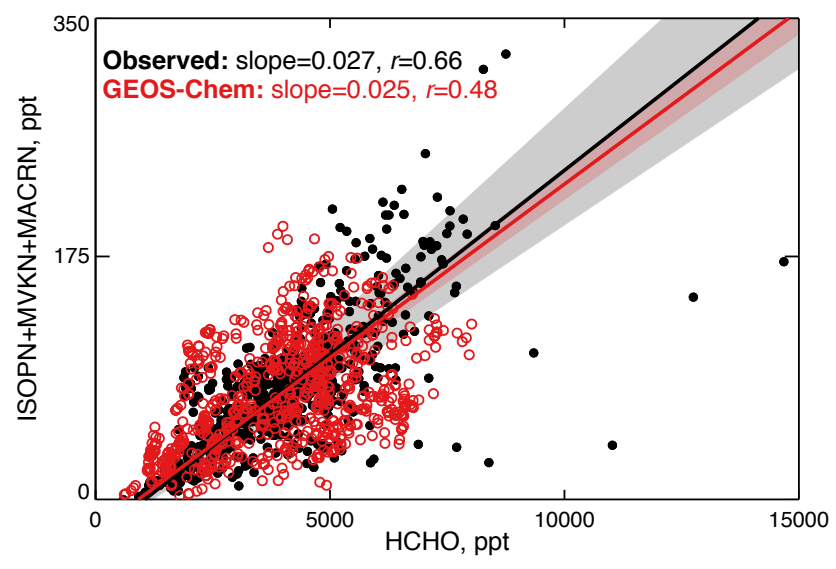

Figure 9. Observed (black) and simulated (red) correlations between $\mathrm{HCHO}$ and the sum of major isoprene nitrates produced via daytime isoprene oxidation (ISOPN+MVKN+MACRN) in Southeast US surface air $(<1 \mathrm{~km})$ during SEAC $^{4} \mathrm{RS}$. Thick solid lines indicate the best fit as calculated from a reduced major axis regression, and shaded areas show the $95 \%$ confidence interval on the regression slope as determined by bootstrap resampling. The regression slopes and correlation coefficients are given inset.

speciated $\mathrm{RONO}_{2}=198 \mathrm{ppt}$ ). Figure 10a also shows the median surface $\Sigma$ ANs measured during SOAS (198 ppt; black triangle). As for $\mathrm{SEAC}^{4} \mathrm{RS}$, SOAS total speciated $\mathrm{RONO}_{2}$ is much lower $(82 \mathrm{ppt})$ when calculated from the CIT-ToFCIMS and AMS measurements. The gap is smaller, but still 
exists, when calculated using ISOPN from the Purdue CIMS (total $\mathrm{RONO}_{2}=102 \mathrm{ppt}$ ) or $\mathrm{pRONO}_{2}$ from the TD-LIF (total $\left.\mathrm{RONO}_{2}=139 \mathrm{ppt}\right)$. An independent thermal dissociation instrument operated by the SouthEastern Aerosol Research and Characterization (SEARCH) network also measured $\Sigma$ ANs at the SOAS site and showed values that were $80 \mathrm{ppt} \mathrm{higher}$ than measured by the TD-LIF (but generally well correlated, with a slope close to 1 and $r \sim 0.8$ ).

Some of the difference between the total speciated $\mathrm{RONO}_{2}$ and $\Sigma$ ANs measurements can be attributed to gas-phase nitrates not measured by CIT-ToF-CIMS or WAS. A number of these were identified during SOAS using a second ToF-CIMS operated by the University of Washington (Lee et al., 2016). In addition, SEAC ${ }^{4} \mathrm{RS}$ observations of total $\mathrm{NO}_{\mathrm{y}}\left(\equiv \mathrm{NO}_{x}+\mathrm{HNO}_{3}+\mathrm{PAN}+\mathrm{RONO}_{2}\right.$, including $\left.\mathrm{pRONO}_{2}\right)$ are better balanced by including the $\Sigma$ ANs than the speciated $\mathrm{RONO}_{2}$ components $\approx 81 \%$ vs. $70 \%$ of surface $\mathrm{NO}_{\mathrm{y}}$, compared to $56 \%$ with no $\mathrm{RONO}_{2}$ contribution). Also contributing to the discrepancy are the large uncertainties still associated with $\mathrm{RONO}_{2}$ measurement techniques. Lee et al. (2016) found that SOAS measurements of $\mathrm{pRONO}_{2}$ differ by factors of 2-4, as also shown in Fig. S3, with the AMS lower than TD-LIF. Similarly, we showed in Sect. 3 that the two SOAS measurements of ISOPN differ by up to a factor of 2 (CIT-ToF-CIMS lower than Purdue CIMS, for reasons that remain unclear). Assuming similar uncertainties characterize the $\mathrm{SEAC}^{4} \mathrm{RS} \mathrm{RONO}_{2}$ measurements, these could readily explain some of the inability of the speciated measurements to close the $\Sigma$ ANs budget in Fig. 10a.

Comparison of GEOS-Chem to the two total $\mathrm{RONO}_{2}$ estimates in Fig. 10a shows that the model greatly underestimates SEAC ${ }^{4} \mathrm{RS} \Sigma$ ANs relative to the TD-LIF measurement, with a much smaller underestimate relative to the speciated sum. The better fit to the speciated measurements than to the $\Sigma$ ANs is consistent with the model's ability to match both individual gas-phase $\mathrm{RONO}_{2}$ species measured by the CIT-ToF-CIMS and total $\mathrm{pRONO}_{2}$ measured by the AMS (Sect. 3). During SOAS, Fig. 8 shows that GEOS-Chem can reproduce much of the temporal variability in the $\Sigma$ ANs $(r=0.57)$ with little bias.

\section{2 $\mathrm{RONO}_{2}$ composition}

Figure 10b compares the observed and simulated $\mathrm{RONO}_{2}$ composition in the Southeast US during SEAC ${ }^{4}$ RS. For clarity, only the speciated measurements are shown in the figure. The observations show a constant 20-30 ppt background at all altitudes from small $\left(\mathrm{C}_{1}-\mathrm{C}_{3}\right) \mathrm{RONO}_{2}$ produced from anthropogenic VOCs. The contributions of these small nitrates are consistent with the observed concentrations of their parent VOCs and with known reaction rate constants (Atkinson and Arey, 2003), $\mathrm{RONO}_{2}$ yields (Perring et al., 2013), and $\mathrm{RONO}_{2}$ lifetimes (Talukdar et al., 1997; Dahl et al., 2005; Worton et al., 2010) assuming steady state. GEOSChem does not simulate these nitrates under the assump-
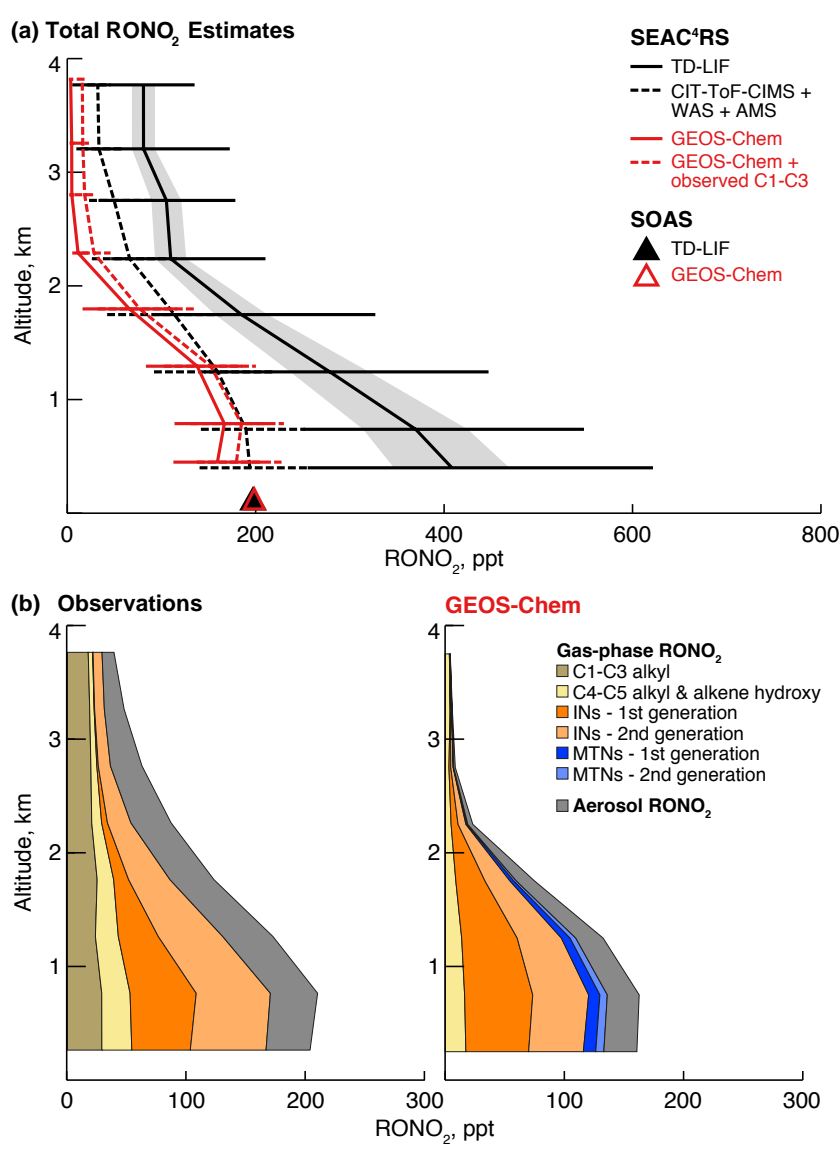

Figure 10. (a) Median vertical profiles of estimated total $\mathrm{RONO}_{2}$ over the Southeast US during SEAC ${ }^{4}$ RS. For the observations, the solid black line indicates the TD-LIF $\Sigma$ ANs measurements (with gray shading for the measurement uncertainty) and the dashed black line the sum of CIT-ToF-CIMS, WAS, and AMS measurements of individual $\mathrm{RONO}_{2}$ species (gas-phase and particulate). For the model, the solid red line indicates the total simulated $\mathrm{RONO}_{2}$ and the dashed red line the sum of the total simulated $\mathrm{RONO}_{2}$ plus measured $\leq \mathrm{C}_{3}$ RONO2 that are not included in the simulation. Triangles compare the total $\mathrm{RONO}_{2}$ during SOAS from TD-LIF $\Sigma$ ANs and GEOS-Chem. (b) Mean $\mathrm{RONO}_{2}$ composition from the observations (CIT-ToF-CIMS, WAS, and AMS) and the model. Isoprene nitrates (INs) include first generation (ISOPN, plus ISN1 for GEOSChem) and second generation INs (MVKN+MACRN, PROPNN, ETHLN, NISOPOOH, plus DHDN for GEOS-Chem). Monoterpene nitrates (MTNs) are shown for the model only and include first and second generation contributions. Other gas-phase $\mathrm{RONO}_{2}$ (yellow, brown) are mainly anthropogenic and do not represent the same species between the model and the observations.

tion that their contributions to total $\mathrm{NO}_{\mathrm{y}}$ are insignificant. The SEAC ${ }^{4} \mathrm{RS}$ data clearly show that this assumption is not valid, at least for the US, where natural gas production is a large alkane source, and is contributing to model bias in both $\mathrm{RONO}_{2}$ and $\mathrm{NO}_{\mathrm{y}}$. Given the long lifetimes (weeks-months) of the small nitrates, the bias is particularly acute in the free troposphere and has implications for global $\mathrm{N}$ export. 
In both observations and model, gas-phase INs (orange) account for half of speciated $\mathrm{RONO}_{2}$ (25\% of $\Sigma \mathrm{ANs}$ ), split roughly equally between first and second generation species. The model underestimates somewhat the second generation INs, as seen previously in Figs. 5 and 7. In the model, gasphase MTNs from monoterpenes (blue; not measured during SEAC $\left.{ }^{4} \mathrm{RS}\right)$ account for an additional $10 \%$ of simulated $\mathrm{RONO}_{2}(\sim 5 \%$ relative to $\Sigma \mathrm{ANs})$. Previous studies during ICARTT also found a $10 \%$ MTN contribution to $\mathrm{RONO}_{2}$ (Horowitz et al., 2007; Perring et al., 2009a), although MTNs have been neglected in more recent simulations (e.g., Mao et al., 2013; Xie et al., 2013). Other $\mathrm{C}_{4}-\mathrm{C}_{5}$ nitrates (yellow, including alkyl nitrates from WAS and alkene hydroxynitrates from CIT-ToF-CIMS) similarly contribute 5-10\% of observed $\mathrm{RONO}_{2}$; these are underestimated by $50 \%$ in GEOS-Chem because the model does not include nitrate formation from anthropogenic alkenes.

A significant fraction (10-20\%) of $\mathrm{RONO}_{2}$ was in the aerosol phase during SEAC ${ }^{4} \mathrm{RS}$. The model underestimates the observed $\mathrm{pRONO}_{2}$ contribution in the free troposphere; however, some caution should be used when interpreting these data. Observed $\mathrm{pRONO}_{2}$ is the product of measured total aerosol nitrate and the measured organic fraction of the nitrate aerosol, but during SEAC ${ }^{4} \mathrm{RS}$ the organic fraction was often not reported in the free troposphere due to interference from dust layers and instrumental issues. In these instances, the organic fraction of measured nitrate is assumed to be 0.8 , based largely on surface measurements from multiple campaigns (Day et al., 2016). In the free troposphere $(>1.5 \mathrm{~km})$, this assumption is applied to $85 \%$ of the $\mathrm{SEAC}^{4} \mathrm{RS} 1 \mathrm{~min}$ data, and could lead to a high bias in the $\mathrm{pRONO}_{2}$ observations. Nonetheless, it is also likely that simulated $\mathrm{pRONO}_{2}$ is underestimated because of our assumption that all $\mathrm{pRONO}_{2}$ species undergo rapid hydrolysis. In fact, many of the nitrates produced from BVOC oxidation are not expected to hydrolyze at all (Boyd et al., 2015; Pye et al., 2015), and so would have lifetimes sufficiently long for export out of the boundary layer.

Our simulated $\mathrm{RONO}_{2}$ composition in Fig. 10b suggests a less important role for INs than identified from recent simulations of the ICARTT data. In an earlier version of GEOSChem, INs alone could explain all measured $\Sigma$ ANs during ICARTT ( 200 ppt at the surface; Mao et al., 2013), and both that model and a CMAQ simulation (Xie et al., 2013) suggested INs were dominated by second generation species (70-90\% of total INs). These earlier simulations did not account for either aerosol uptake and possible hydrolysis (Darer et al., 2011; Jacobs et al., 2014) or fast photolysis (Müller et al., 2014) of second generation INs, and so lifetimes were significantly longer than in our simulation. We performed sensitivity simulations without these additional IN sinks and found that the model overestimated observed second generation INs by a factor of 3-5 during SEAC ${ }^{4} \mathrm{RS}$. It seems likely that second generation IN overestimates in previous work were compensated for by omitting the con- tributions from MTNs and $\mathrm{pRONO}_{2}$. Here, we find MTN and $\mathrm{pRONO}_{2}$ combined contribute as much to total $\mathrm{RONO}_{2}$ as either first or second generation INs alone, and that excluding them would lead to major model shortcomings. The pRONO ${ }_{2}$ contribution is especially important as different removal processes for gas-phase vs. particulate species would have different implications for $\mathrm{NO}_{x}$ budgets and $\mathrm{N}$ deposition.

\section{Fate of organic nitrates and implications for nitrogen budgets}

Table 1 summarizes the dominant fates and lifetimes of individual gas-phase $\mathrm{RONO}_{2}$ in the Southeast US boundary layer during the SEAC ${ }^{4} \mathrm{RS}$ campaign (12 August-23 September) as calculated from GEOS-Chem. The contribution of different fates to total gas-phase $\mathrm{RONO}_{2}$ loss is illustrated in Fig. 11a. Loss processes that recycle $\mathrm{RONO}_{2}$ by converting between $\mathrm{RONO}_{2}$ species (e.g., from first to second generation) are not included. Total simulated $\mathrm{RONO}_{2}$ loss is dominated by aerosol hydrolysis, with an additional large loss to deposition that is consistent with the rapid deposition fluxes of both INs and MTNs observed during SOAS (Nguyen et al., 2015). The large predicted losses to aerosol influence simulation of both $\mathrm{pRONO}_{2}$ (for which uptake is the only source in the model) and $\mathrm{HNO}_{3}$ (which is produced during $\mathrm{pRONO}_{2}$ hydrolysis). We find here that our simulation including a large sink to aerosol is consistent with observed surface $\mathrm{pRONO}_{2}$ concentrations and variability (Figs. 8 and 10), $\mathrm{HNO}_{3}$ concentrations (Travis et al., 2016, Fig. 2), and nitrate wet deposition fluxes (Travis et al., 2016, Fig. 3) during SEAC ${ }^{4} \mathrm{RS}$ and SOAS.

Overall, more than $80 \%$ of simulated gas-phase $\mathrm{RONO}_{2}$ are lost via processes that irreversibly remove nitrogen from the atmosphere (deposition, aerosol hydrolysis). The remainder is primarily lost via photolysis, driven largely by the fast photolysis of second generation carbonyl INs (Müller et al., 2014). Romer et al. (2016) similarly found that terminal $\mathrm{NO}_{x}$ sinks dominated $\mathrm{RONO}_{2}$ loss processes during SOAS, responsible for $55 \% \pm 20 \%$ of total loss, primarily due to aerosol hydrolysis. $\mathrm{RONO}_{2}$ lifetimes are too short (minutes-hours, Table 1 and Romer et al., 2016) for significant transport to occur, and simulated $\mathrm{RONO}_{2}$ loss typically occurs only a short distance from sources. Summed over the Southeast US domain, we find gross $\mathrm{RONO}_{2}$ production and loss are roughly balanced $\left(640 \mathrm{Mg} \mathrm{N} \mathrm{d}^{-1}\right)$. This balance implies that BVOC-derived gas-phase $\mathrm{RONO}_{2}$ are not generally exported from the Southeast US, in agreement with earlier work (Horowitz et al., 2007; Hudman et al., 2007; Fang et al., 2010; Mao et al., 2013). However, this calculation excludes the longer-lived small alkyl nitrates and non-hydrolyzing particulate nitrates not simulated in GEOSChem (Sect. 4). These may be an important source of ex- 
(a) Gas-phase $\mathrm{RONO}_{2}$ Sinks (642 $\mathrm{Mg} \mathrm{N} \mathrm{d}^{-1}$ )

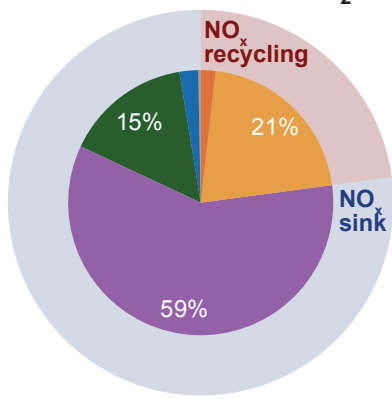

Oxidation

Photolysis

Aerosol hydrolysis

Dry deposition

Wet deposition

Other (b) Terminal $\mathrm{NO}_{\mathrm{x}}$ Sinks $\left(2.18 \mathrm{Gg} \mathrm{N} \mathrm{d}^{-1}\right)$

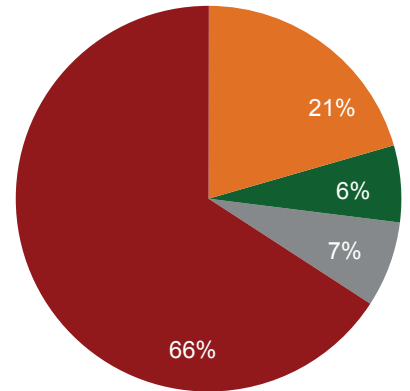

Net loss to RONO

Dry deposition

Net export

Net non-RONO chemistry (mostly $\mathrm{NO}_{2}+\mathrm{OH}$ )

Figure 11. Simulated relative importance of gas-phase loss processes (\%) in the Southeast US boundary layer $\left(80-94.5^{\circ} \mathrm{W}, 29.5-40^{\circ} \mathrm{N}\right.$, $<2 \mathrm{~km}$ ) during August-September 2013 for (a) gas-phase $\mathrm{RONO}_{2}$ and (b) $\mathrm{NO}_{x}$. In (a), outer circles group losses into those that recycle $\mathrm{NO}_{x}$ (pale red) and those that serve as terminal $\mathrm{NO}_{x}$ sinks (pale blue). Loss processes that recycle $\mathrm{RONO}_{2}$ by converting between $\mathrm{RONO}_{2}$ species (e.g., first to second generation) are not included. In (b), net loss to $\mathrm{RONO}_{2}$ is calculated as the difference between $\mathrm{NO}_{x}$ consumed during $\mathrm{RONO}_{2}$ production and $\mathrm{NO}_{x}$ recycled during $\mathrm{RONO}_{2}$ loss, with recycling efficiencies from (a). Net non- $\mathrm{RONO}_{2}$ chemistry is the difference between $\mathrm{NO}_{x}$ chemical production and chemical loss excluding all $\mathrm{RONO}_{2}$ chemistry, and net export is the difference between emissions and all other sinks. Absolute loss rates from all processes combined are given in the sub-plot titles.

ported reactive nitrogen, and their inclusion should be a priority for future model development.

The impacts of $\mathrm{RONO}_{2}$ production and other loss processes on the $\mathrm{NO}_{x}$ budget are shown in Fig. 11b for the Southeast US boundary layer in August-September 2013. Non- $\mathrm{RONO}_{2}$ losses in the figure are mainly $\mathrm{HNO}_{3}$ formation, with an additional contribution from PANs (relevant in regions with elevated $\mathrm{NO}_{x}$; Browne and Cohen, 2012). We find in the model that gross $\mathrm{NO}_{x}$ loss due to $\mathrm{RONO}_{2}$ production is $35 \mathrm{Gg} \mathrm{N}$ over this period. As shown in Fig. 11a, only $23 \%$ of this $\mathrm{RONO}_{2}(8 \mathrm{GgN})$ goes on to recycle $\mathrm{NO}_{x}$. We therefore find that $\mathrm{RONO}_{2}$ production serves as a net $\mathrm{NO}_{x}$ sink of $27 \mathrm{Gg} \mathrm{N}$ in the Southeast US in summer, equivalent to $21 \%$ of $\mathrm{NO}_{x}$ emitted in this region and season.

These regional-scale averages conceal important spatial variability. Figure 12 shows how the $\mathrm{NO}_{x}$ sink due to $\mathrm{RONO}_{2}$ production varies spatially across the Southeast US in summer, and how this depends on the ratio between BVOC and $\mathrm{NO}_{x}$ emissions $\left(E_{\mathrm{BVOC}} / E_{\mathrm{NO}_{x}}\right)$. The fractional $\mathrm{NO}_{x}$ sink to $\mathrm{RONO}_{2}$ is strongly correlated $(r=0.90)$ with the $E_{\mathrm{BVOC}} / E_{\mathrm{NO}_{x}}$ ratio. Our finding that $\mathrm{RONO}_{2}$ production dominates $\mathrm{NO}_{x}$ loss in very low- $\mathrm{NO}_{x}$ environments is consistent with an earlier analysis for boreal Canada (Browne and Cohen, 2012), which found the fractional sink to $\mathrm{RONO}_{2}$ approached unity for $\left[\mathrm{NO}_{x}\right]<50 \mathrm{ppt}$, and with analysis of a subset of the $\mathrm{SEAC}^{4} \mathrm{RS}$ data from the low- $\mathrm{NO}_{x}$ Ozarks Mountains (Wolfe et al., 2015).

Figure $12 \mathrm{c}$ shows how the fractional $\mathrm{NO}_{x}$ sink to $\mathrm{RONO}_{2}$ (blue) and the $E_{\mathrm{BVOC}} / E_{\mathrm{NO}_{x}}$ emission ratio (red) vary as a function of $\mathrm{NO}_{x}$ emissions (gray, shown as their cumulative distribution binned into $5 \%$ quantiles). Both are inversely related to $\mathrm{NO}_{x}$ emissions. We see from the figure that $\mathrm{RONO}_{2}$ production is the dominant $\mathrm{NO}_{x}$ sink for regions that account for the lowest $5 \%$ of total Southeast US $\mathrm{NO}_{x}$ emissions (leftmost bar in Fig. 12c), but the importance of the sink drops off rapidly as $\mathrm{NO}_{x}$ emissions increase. By the time $30 \%$ of the regional $\mathrm{NO}_{x}$ emissions are accounted for, the fractional sink has dropped to 0.2 , and from there continues to decline to a minimum of 0.03 in the highest-emitting regions.

The mean $E_{\mathrm{BVOC}} / E_{\mathrm{NO}_{x}}$ ratio averaged over the Southeast US is 5.3 and is highlighted as the white point in Fig. 12c. The figure shows that most Southeast US $\mathrm{NO}_{x}$ emission $(\sim 65 \%)$ occurs at $E_{\mathrm{BVOC}} / E_{\mathrm{NO}_{x}}$ ratios that are significantly lower than the regional mean, highlighting the significant spatial segregation between $\mathrm{NO}_{x}$ and $\mathrm{BVOC}$ emissions in this region (Yu et al., 2016).

Emissions projections for the Southeast US anticipate continued decreases in $\mathrm{NO}_{x}$ emissions (and concomitant increases in the $E_{\mathrm{BVOC}} / E_{\mathrm{NO}_{x}}$ ratio). While these changes should increase the importance of $\mathrm{RONO}_{2}$ for the $\mathrm{NO}_{x}$ budget, the relationship shown in Fig. 12c suggests very large emissions decreases will be necessary before $\mathrm{RONO}_{2}$ becomes a major regional sink for $\mathrm{NO}_{x}$. The figure shows that the sink to $\mathrm{RONO}_{2}$ is only sensitive to $\mathrm{NO}_{x}$ emissions in regions where they are already low: a $10 \%$ decrease in total Southeast US $\mathrm{NO}_{x}$ emissions (e.g., a leftward shift by two bars in the figure) would increase the importance of the sink by less than $0.5 \%$. The actual rate at which $\mathrm{NO}_{x}$ emissions in the Southeast US will decrease varies widely among different projections. Under the Representative Concentration Pathway 8.5 (RCP8.5), for example, the Southeast US would see a decrease (relative to 2013 emissions) of $45 \%$ by 2050 to $\sim 1300 \mathrm{Mg} \mathrm{N} \mathrm{d}^{-1}$; according to Fig. 12 , the $\mathrm{RONO}_{2}$ sink would still only account for about $10 \%$ of the loss in the highest-emitting regions. Under the more aggressive RCP4.5, emissions would decline by $65 \%$ to $\sim 800 \mathrm{Mg} \mathrm{N}$ day $^{-1}$ in 2050 . At this stage, the $\mathrm{RONO}_{2}$ sink would become significant (> $20 \%$ ) throughout the region. 
(a) Fraction $\mathrm{NO}_{x}$ lost to $\mathrm{RONO}_{2}$

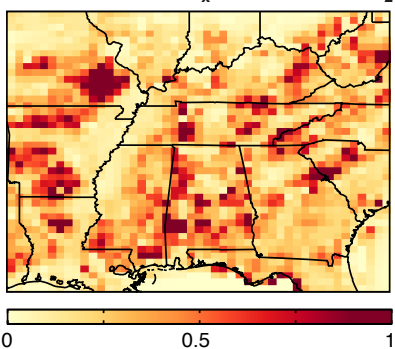

(b) $\mathrm{E}_{\mathrm{Bvoc}} / \mathrm{E}_{\mathrm{NOX}}$ ratio

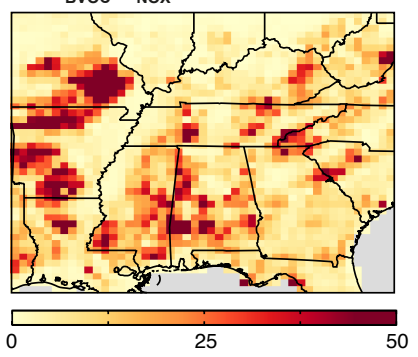

(c) Relationship with Southeast US $\mathrm{NO}_{x}$ emissions

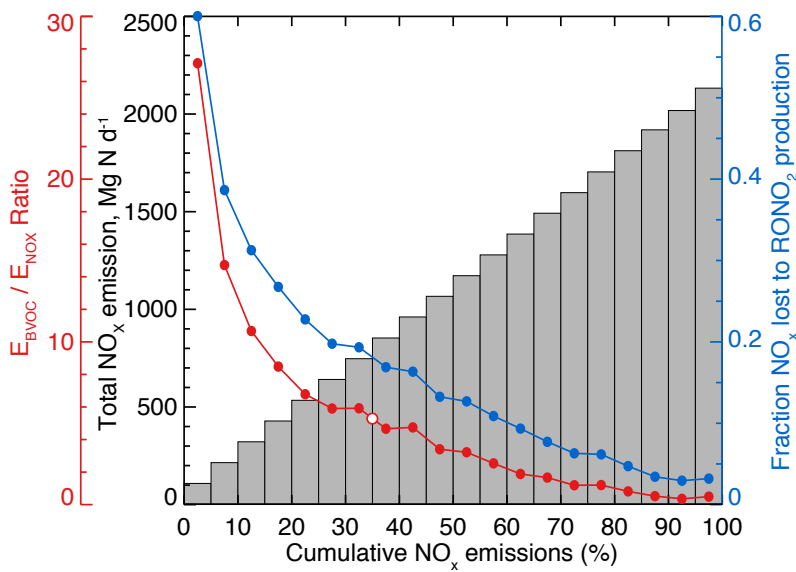

Figure 12. Importance of organic nitrates as a sink for $\mathrm{NO}_{x}$, as a function of BVOC and $\mathrm{NO}_{x}$ emissions. (a) Simulated fraction of emitted $\mathrm{NO}_{x}$ that is lost to $\mathrm{RONO}_{2}$ production in Southeast US surface air. (b) Ratio of BVOC (isoprene + monoterpene) emissions $\left(E_{\mathrm{BVOC}}\right)$ to $\mathrm{NO}_{x}$ emissions $\left(E_{\mathrm{NO}_{x}}\right)$. (c) Mean values of variables from (a) and (b) as a function of cumulative $\mathrm{NO}_{x}$ emissions in the Southeast US. Model grid squares have been sorted by $\mathrm{NO}_{x}$ emissions, then grouped into bins that each represent $5 \%$ of total Southeast US $\mathrm{NO}_{x}$ emissions. Values shown for the fractional $\mathrm{NO}_{x}$ sink due to $\mathrm{RONO}_{2}$ production (blue) and the mean $E_{\mathrm{BVOC}} / E_{\mathrm{NO}_{x}}$ emissions ratio (red) represent the mean within each bin. $\mathrm{NO}_{x}$ emissions are shown as cumulative totals (gray) in $\mathrm{MgNday}^{-1}$. The Southeast US mean $E_{\mathrm{BVOC}} / E_{\mathrm{NO}_{x}}$ emissions ratio (5.3) is highlighted with a white circle.

\section{Conclusions}

We have used airborne and ground-based observations from two summer 2013 campaigns in the Southeast US (SEAC ${ }^{4} \mathrm{RS}$, SOAS) to better understand the chemistry and impacts of alkyl and multifunctional organic nitrates $\left(\mathrm{RONO}_{2}\right)$. We used the observations, along with findings from recent laboratory, field, and modeling studies, to update and evaluate biogenic volatile organic compound (BVOC) oxidation schemes in the GEOS-Chem chemical transport model (CTM). From there, we used the updated CTM with $0.25^{\circ} \times 0.3125^{\circ}\left(\sim 25 \times 25 \mathrm{~km}^{2}\right)$ horizontal resolution to examine $\mathrm{RONO}_{2}$ speciation, chemical production/loss processes, and importance as a sink for $\mathrm{NO}_{x}$.
Our improved mechanism provides a state-of-the-science description of isoprene oxidation in the presence of $\mathrm{NO}_{x}$, with updates including a $9 \%$ isoprene nitrate (IN) yield (Xiong et al., 2015), an increase in the population of $\beta$-vs. $\delta$-hydroxyl isomers (Peeters et al., 2014), revised IN reaction rate constants and products (Jacobs et al., 2014; Lee et al., 2014), fast photolysis of carbonyl INs (Müller et al., 2014), rapid IN dry deposition (Nguyen et al., 2015), and a simplified scheme for aerosol partitioning of soluble INs (Xu et al., 2014; Marais et al., 2016) followed by particle-phase hydrolysis (Jacobs et al., 2014; Rindelaub et al., 2015). For the first time in GEOS-Chem, we have also added both OHand $\mathrm{NO}_{3}$-initiated monoterpene oxidation leading to the formation of monoterpene nitrates (MTNs), with similar loss processes as for INs. With these updates, GEOS-Chem simulates surface-level $\mathrm{BVOC}$ and $\mathrm{RONO}_{2}$ mixing ratios that are generally within the observed variability of the SEAC ${ }^{4} \mathrm{RS}$ and SOAS data.

Observed first generation IN (ISOPN) variability is generally reproduced without bias by GEOS-Chem, except at midday when modeled ISOPN peaks, while SOAS observations indicate a gradual decline. For second generation INs, the model shows more skill for species produced primarily from $\beta$-hydroxyl isomers (MVKN+MACRN) than those from $\delta$-hydroxyl isomers and $\mathrm{NO}_{3}$-initiated chemistry (PROPNN+ETHLN). For the latter, GEOS-Chem underestimates both magnitudes and variability relative to the SEAC ${ }^{4} \mathrm{RS}$ observations. While this could imply a more important role for $\delta$-channel oxidation than included in our mechanism, theoretical considerations suggest that our assumed $\delta$-hydroxyl contribution is already an upper limit (Peeters et al., 2014), and more measurements are needed to reconcile these theoretical and observational constraints. Better understanding of nighttime $\mathrm{NO}_{3}$-initiated isoprene oxidation could also play an important role in improving simulation of second generation INs.

The SEAC ${ }^{4}$ RS observations imply that gas-phase INs account for $25-50 \%$ of total surface $\mathrm{RONO}_{2}$, much less than inferred from previous modeling studies (Mao et al., 2013; Xie et al., 2013). GEOS-Chem reproduces this contribution and attributes an additional $10 \%$ of $\mathrm{RONO}_{2}$ to MTNs. Both observations and model show $10-20 \%$ of the remaining $\mathrm{RONO}_{2}$ at the surface is in the particle phase $\left(\mathrm{pRONO}_{2}\right)$. In the free troposphere, GEOS-Chem greatly underestimates total $\mathrm{RONO}_{2}$ by ignoring contributions from small, long-lived nitrates derived from anthropogenic VOCs and from nonhydrolyzing particulate species. This has a significant impact on simulation of reactive nitrogen export from the United States and should be remedied in future model development.

We find in the model that formation of $\mathrm{pRONO}_{2}$ via aerosol uptake, followed by particle-phase hydrolysis, is the dominant loss process for gas-phase $\mathrm{RONO}_{2}$. Including this large sink to aerosol results in simulated $\mathrm{RONO}_{2}, \mathrm{pRONO}_{2}$, and $\mathrm{HNO}_{3}$ mixing ratios and nitrate deposition fluxes that are consistent with observations. $\mathrm{RONO}_{2}$ loss via deposition 
is also significant, with $\mathrm{RONO}_{2}$ (both gas-phase and particulate) responsible for $\sim 3 \%$ of total $\mathrm{N}$ deposition over the Southeast US in summer.

Overall, less than a quarter of simulated gas-phase $\mathrm{RONO}_{2}$ loss recycles atmospheric $\mathrm{NO}_{x}$. We find in the model that $\mathrm{RONO}_{2}$ production accounts for $21 \%$ of the net sink of $\mathrm{NO}_{x}$ emitted in the Southeast US in summer. $\mathrm{RONO}_{2}$ production is the dominant $\mathrm{NO}_{x}$ sink only in regions where elevated BVOC emissions are paired with very low $\mathrm{NO}_{x}$ emissions. Elsewhere, the importance of the sink declines rapidly as a function of $\mathrm{NO}_{x}$ emissions. Most of the Southeast US $\mathrm{NO}_{x}$ is emitted in locations where BVOC emissions are relatively low, limiting the importance of $\mathrm{RONO}_{2}$ as a $\mathrm{NO}_{x}$ sink.

Southeast US $\mathrm{NO}_{x}$ emissions have been declining for the past 2 decades (Hidy et al., 2014; Simon et al., 2015) and further reductions are projected (Lamarque et al., 2011; EPA, 2014). Previous studies have suggested these declines will trigger a more important role for $\mathrm{RONO}_{2}$ as a $\mathrm{NO}_{x}$ sink in future (Browne and Cohen, 2012). In contrast, we find here that the $\mathrm{NO}_{x}$ sink to $\mathrm{RONO}_{2}$ is only sensitive to $\mathrm{NO}_{x}$ emissions in regions where they are already low because of the spatial segregation between $\mathrm{NO}_{x}$ and BVOC emissions. We find that a $10 \%$ decrease in Southeast US $\mathrm{NO}_{x}$ emissions would enhance the importance of this sink by less than $0.5 \%$. $\mathrm{HNO}_{3}$ formation and deposition is likely to remain the dominant sink for $\mathrm{NO}_{x}$ even as $\mathrm{NO}_{x}$ emissions decrease.

\section{Data availability}

The SEAC4RS airborne trace gas and particle measurements are available from the NASA Atmospheric Science Data Centre (https://eosweb. larc.nasa.gov/project/seac4rs/seac4rs_table) with doi:10.5067/Aircraft/SEAC4RS/Aerosol-TraceGas-Cloud.

\section{The Supplement related to this article is available online at doi:10.5194/acp-16-5969-2016-supplement.}

Acknowledgements. We are grateful to the entire NASA SEAC ${ }^{4} \mathrm{RS}$ team for their help in the field, and we thank Eleanor Browne and Fabien Paulot for helpful discussions about the monoterpene nitrate scheme. This work was funded by a University of Wollongong Vice Chancellor's Postdoctoral Fellowship to J. A. Fisher and by the NASA Tropospheric Chemistry Program. This research was undertaken with the assistance of resources provided at the NCI National Facility systems at the Australian National University through the National Computational Merit Allocation Scheme supported by the Australian Government. J. Mao acknowledges supports from the NOAA Climate Program Office grant NA13OAR4310071. J. L. Jimenez, P. Campuzano-Jost, W. Hu, and D. A. Day were supported by NASA NNX15AH33A and NNX15AT96G, NSF AGS-1243354 and AGS-1360834, and EPRI 10004734. Isoprene and monoterpene measurements during SEAC ${ }^{4} \mathrm{RS}$ were supported by the Austrian Federal Ministry for Transport, Innovation and Technology (bmvit) through the Austrian Space Applications Programme (ASAP) of the Austrian Research Promotion Agency (FFG). A. Wisthaler and T. Mikoviny received support from the Visiting Scientist Program at the National Institute of Aerospace (NIA).

Edited by: C. H. Song

\section{References}

Amos, H. M., Jacob, D. J., Holmes, C. D., Fisher, J. A., Wang, Q., Yantosca, R. M., Corbitt, E. S., Galarneau, E., Rutter, A. P., Gustin, M. S., Steffen, A., Schauer, J. J., Graydon, J. A., Louis, V. L. St., Talbot, R. W., Edgerton, E. S., Zhang, Y., and Sunderland, E. M.: Gas-particle partitioning of atmospheric $\mathrm{Hg}$ (II) and its effect on global mercury deposition, Atmos. Chem. Phys., 12, 591-603, doi:10.5194/acp-12-591-2012, 2012.

Aschmann, S. M., Atkinson, R., and Arey, J.: Products of reaction of OH radicals with $\alpha$-pinene, J. Geophys. Res., 107, ACH 6-1ACH 6-7, doi:10.1029/2001jd001098, 2002.

Atkinson, R. and Arey, J.: Atmospheric Degradation of Volatile Organic Compounds, Chem. Rev., 103, 4605-4638, doi:10.1021/cr0206420, 2003.

Ayres, B. R., Allen, H. M., Draper, D. C., Brown, S. S., Wild, R. J., Jimenez, J. L., Day, D. A., Campuzano-Jost, P., Hu, W., de Gouw, J., Koss, A., Cohen, R. C., Duffey, K. C., Romer, P., Baumann, K., Edgerton, E., Takahama, S., Thornton, J. A., Lee, B. H., Lopez-Hilfiker, F. D., Mohr, C., Wennberg, P. O., Nguyen, T. B., Teng, A., Goldstein, A. H., Olson, K., and Fry, J. L.: Organic nitrate aerosol formation via $\mathrm{NO}_{3}+$ biogenic volatile organic compounds in the southeastern United States, Atmos. Chem. Phys., 15, 13377-13392, doi:10.5194/acp-15-13377-2015, 2015.

Barnes, I., Becker, K. H., and Zhu, T.: Near UV absorption spectra and photolysis products of difunctional organic nitrates: Possible importance as NO x reservoirs, J. Atmos. Chem., 17, 353-373, doi:10.1007/BF00696854, 1993.

Beaver, M. R., Clair, J. M. St., Paulot, F., Spencer, K. M., Crounse, J. D., LaFranchi, B. W., Min, K. E., Pusede, S. E., Wooldridge, P. J., Schade, G. W., Park, C., Cohen, R. C., and Wennberg, P. O.: Importance of biogenic precursors to the budget of organic nitrates: observations of multifunctional organic nitrates by CIMS and TD-LIF during BEARPEX 2009, Atmos. Chem. Phys., 12, 5773-5785, doi:10.5194/acp-12-5773-2012, 2012.

Boyd, C. M., Sanchez, J., Xu, L., Eugene, A. J., Nah, T., Tuet, W. Y., Guzman, M. I., and Ng, N. L.: Secondary organic aerosol formation from the $\beta$-pinene $+\mathrm{NO}_{3}$ system: effect of humidity and peroxy radical fate, Atmos. Chem. Phys., 15, 7497-7522, doi:10.5194/acp-15-7497-2015, 2015.

Brown, S. S., deGouw, J. A., Warneke, C., Ryerson, T. B., Dubé, W. P., Atlas, E., Weber, R. J., Peltier, R. E., Neuman, J. A., Roberts, J. M., Swanson, A., Flocke, F., McKeen, S. A., Brioude, J., Sommariva, R., Trainer, M., Fehsenfeld, F. C., and Ravishankara, A. R.: Nocturnal isoprene oxidation over the Northeast United States in summer and its impact on reactive nitrogen partitioning and secondary organic aerosol, Atmos. Chem. Phys., 9, 30273042, doi:10.5194/acp-9-3027-2009, 2009. 
Brown, S. S., Dubé, W. P., Bahreini, R., Middlebrook, A. M., Brock, C. A., Warneke, C., de Gouw, J. A., Washenfelder, R. A., Atlas, E., Peischl, J., Ryerson, T. B., Holloway, J. S., Schwarz, J. P., Spackman, R., Trainer, M., Parrish, D. D., Fehshenfeld, F. C., and Ravishankara, A. R.: Biogenic VOC oxidation and organic aerosol formation in an urban nocturnal boundary layer: aircraft vertical profiles in Houston, TX, Atmos. Chem. Phys., 13, 11317-11337, doi:10.5194/acp-13-11317-2013, 2013.

Browne, E. C. and Cohen, R. C.: Effects of biogenic nitrate chemistry on the $\mathrm{NO}_{\mathrm{x}}$ lifetime in remote continental regions, Atmos. Chem. Phys., 12, 11917-11932, doi:10.5194/acp-1211917-2012, 2012.

Browne, E. C., Wooldridge, P. J., Min, K.-E., and Cohen, R. C.: On the role of monoterpene chemistry in the remote continental boundary layer, Atmos. Chem. Phys., 14, 1225-1238, doi:10.5194/acp-14-1225-2014, 2014.

Chen, X., Hulbert, D., and Shepson, P. B.: Measurement of the organic nitrate yield from $\mathrm{OH}$ reaction with isoprene, J. Geophys. Res.-Atmos., 103, 25563-25568, 1998.

Crounse, J. D., McKinney, K. A., Kwan, A. J., and Wennberg, P. O.: Measurement of Gas-Phase Hydroperoxides by Chemical Ionization Mass Spectrometry, Analytical Chemistry, 78, 6726-6732, doi:10.1021/ac0604235, 2006.

Dahl, E. E., Yvon-Lewis, S. A., and Saltzman, E. S.: Saturation anomalies of alkyl nitrates in the tropical Pacific Ocean, Geophys. Res. Lett., 32, 120817, doi:10.1029/2005GL023896, 2005.

Darer, A. I., Cole-Filipiak, N. C., O'Connor, A. E., and Elrod, M. J.: Formation and Stability of Atmospherically Relevant IsopreneDerived Organosulfates and Organonitrates, Environ. Sci. Technol., 45, 1895-1902, doi:10.1021/es103797z, 2011.

Day, D. A., Wooldridge, P. J., Dillon, M. B., Thornton, J. A., and Cohen, R. C.: A thermal dissociation laser-induced fluorescence instrument for in situ detection of $\mathrm{NO}_{2}$, peroxy nitrates, alkyl nitrates, and $\mathrm{HNO}_{3}$, J. Geophys. Res.-Atmos., 107, ACH 4-1ACH 4-14, doi:10.1029/2001JD000779, 2002.

Day, D. A., Liu, S., Russell, L. M., and Ziemann, P. J.: Organonitrate group concentrations in submicron particles with high nitrate and organic fractions in coastal southern California, Atmos. Environ., 44, 1970-1979, doi:10.1016/j.atmosenv.2010.02.045, 2010.

Day, D. A., Campuzano-Jost, P., Palm, B. B., Hu, W., Nault, B. A., Wooldridge, P. J., Cohen, R. C., Docherty, K. S., Wagner, N. L., and Jimenez, J.-L.: Observations of particle organic nitrate from airborne and ground platforms in North America: Insights into vertical and geographical distributions, gas/particle partitioning, losses, and contributions to total particle nitrate, in preparation, 2016.

EPA: U.S. Environmental Protection Agency, Technical Support Document (TSD): preparation of Emissions Inventories for the Version 6.1, 2011 Emissions Modeling Platform, Tech. rep., U.S. Environmental Protection Agency, 2014.

Fang, Y., Fiore, A. M., Horowitz, L. W., Levy, H., Hu, Y., and Russell, A. G.: Sensitivity of the NOy budget over the United States to anthropogenic and lightning NOx in summer, J. Geophys. Res.-Atmos., 115, d18312, doi:10.1029/2010JD014079, 2010.

Fiore, A. M., Horowitz, L. W., Purves, D. W., Levy, H., Evans, M. J., Wang, Y., Li, Q., and Yantosca, R. M.: Evaluating the contribution of changes in isoprene emissions to surface ozone trends over the eastern United States, J. Geophys. Res.-Atmos., 110, d12303, doi:10.1029/2004JD005485, 2005.
Fischer, E. V., Jacob, D. J., Yantosca, R. M., Sulprizio, M. P., Millet, D. B., Mao, J., Paulot, F., Singh, H. B., Roiger, A., Ries, L., Talbot, R. W., Dzepina, K., and Pandey Deolal, S.: Atmospheric peroxyacetyl nitrate (PAN): a global budget and source attribution, Atmos. Chem. Phys., 14, 2679-2698, doi:10.5194/acp-142679-2014, 2014.

Fry, J. L., Kiendler-Scharr, A., Rollins, A. W., Wooldridge, P. J., Brown, S. S., Fuchs, H., Dubé, W., Mensah, A., dal Maso, M., Tillmann, R., Dorn, H.-P., Brauers, T., and Cohen, R. C.: Organic nitrate and secondary organic aerosol yield from $\mathrm{NO}_{3}$ oxidation of $\beta$-pinene evaluated using a gas-phase kinetics/aerosol partitioning model, Atmos. Chem. Phys., 9, 14311449, doi:10.5194/acp-9-1431-2009, 2009.

Fry, J. L., Draper, D. C., Zarzana, K. J., Campuzano-Jost, P., Day, D. A., Jimenez, J. L., Brown, S. S., Cohen, R. C., Kaser, L., Hansel, A., Cappellin, L., Karl, T., Hodzic Roux, A., Turnipseed, A., Cantrell, C., Lefer, B. L., and Grossberg, N.: Observations of gas- and aerosol-phase organic nitrates at BEACHON-RoMBAS 2011, Atmos. Chem. Phys., 13, 8585-8605, doi:10.5194/acp-138585-2013, 2013.

Fry, J. L., Draper, D. C., Barsanti, K. C., Smith, J. N., Ortega, J., Winkler, P. M., Lawler, M. J., Brown, S. S., Edwards, P. M., Cohen, R. C., and Lee, L.: Secondary Organic Aerosol Formation and Organic Nitrate Yield from $\mathrm{NO}_{3}$ Oxidation of Biogenic Hydrocarbons, Environ. Sci. Technol., 48, 11944-11953, doi:10.1021/es502204x, 2014.

Goliff, W. S., Stockwell, W. R., and Lawson, C. V.: The regional atmospheric chemistry mechanism, version 2, Atmos. Environ., 68, 174-185, doi:10.1016/j.atmosenv.2012.11.038, 2013.

Guenther, A. B., Jiang, X., Heald, C. L., Sakulyanontvittaya, T., Duhl, T., Emmons, L. K., and Wang, X.: The Model of Emissions of Gases and Aerosols from Nature version 2.1 (MEGAN2.1): an extended and updated framework for modeling biogenic emissions, Geosci. Model Dev., 5, 1471-1492, doi:10.5194/gmd-51471-2012, 2012.

Hidy, G. M., Blanchard, C. L., Baumann, K., Edgerton, E., Tanenbaum, S., Shaw, S., Knipping, E., Tombach, I., Jansen, J., and Walters, J.: Chemical climatology of the southeastern United States, 1999-2013, Atmos. Chem. Phys., 14, 11893-11914, doi:10.5194/acp-14-11893-2014, 2014.

Horowitz, L. W., Liang, J., Gardner, G. M., and Jacob, D. J.: Export of reactive nitrogen from North America during summertime: Sensitivity to hydrocarbon chemistry, J. Geophys. Res.-Atmos., 103, 13451-13476, 1998.

Horowitz, L. W., Fiore, A. M., Milly, G. P., Cohen, R. C., Perring, A., Wooldridge, P. J., Hess, P. G., Emmons, L. K., and Lamarque, J.-F.: Observational constraints on the chemistry of isoprene nitrates over the eastern United States, J. Geophys. Res., 112, doi:10.1029/2006jd007747, 2007.

Hu, K. S., Darer, A. I., and Elrod, M. J.: Thermodynamics and kinetics of the hydrolysis of atmospherically relevant organonitrates and organosulfates, Atmos. Chem. Phys., 11, 8307-8320, doi:10.5194/acp-11-8307-2011, 2011.

Hudman, R. C., Jacob, D. J., Turquety, S., Leibensperger, E. M., Murray, L. T., Wu, S., Gilliland, A. B., Avery, M., Bertram, T. H., Brune, W., Cohen, R. C., Dibb, J. E., Flocke, F. M., Fried, A., Holloway, J., Neuman, J. A., Orville, R., Perring, A., Ren, X., Sachse, G. W., Singh, H. B., Swanson, A., and Wooldridge, P. J.: Surface and lightning sources of nitrogen oxides over the United 
States: Magnitudes, chemical evolution, and outflow, J. Geophys. Res.-Atmos., 112, d12S05, doi:10.1029/2006JD007912, 2007.

Jacobs, M. I., Burke, W. J., and Elrod, M. J.: Kinetics of the reactions of isoprene-derived hydroxynitrates: gas phase epoxide formation and solution phase hydrolysis, Atmos. Chem. Phys., 14, 8933-8946, doi:10.5194/acp-14-8933-2014, 2014.

Kim, H., Barkey, B., and Paulson, S. E.: Real Refractive Indices and Formation Yields of Secondary Organic Aerosol Generated from Photooxidation of Limonene and $\alpha$-Pinene: The Effect of the HC/NO x Ratio, J. Phys. Chem. A, 116, 6059-6067, doi:10.1021/jp301302z, 2012.

Kim, P. S., Jacob, D. J., Fisher, J. A., Travis, K., Yu, K., Zhu, L., Yantosca, R. M., Sulprizio, M. P., Jimenez, J. L., CampuzanoJost, P., Froyd, K. D., Liao, J., Hair, J. W., Fenn, M. A., Butler, C. F., Wagner, N. L., Gordon, T. D., Welti, A., Wennberg, P. O., Crounse, J. D., St. Clair, J. M., Teng, A. P., Millet, D. B., Schwarz, J. P., Markovic, M. Z., and Perring, A. E.: Sources, seasonality, and trends of southeast US aerosol: an integrated analysis of surface, aircraft, and satellite observations with the GEOS-Chem chemical transport model, Atmos. Chem. Phys., 15, 10411-10433, doi:10.5194/acp-15-10411-2015, 2015.

Knote, C., Hodzic, A., and Jimenez, J. L.: The effect of dry and wet deposition of condensable vapors on secondary organic aerosols concentrations over the continental US, Atmos. Chem. Phys., 15, 1-18, doi:10.5194/acp-15-1-2015, 2015.

Lamarque, J.-F., Kyle, G., Meinshausen, M., Riahi, K., Smith, S., van Vuuren, D., Conley, A., and Vitt, F.: Global and regional evolution of short-lived radiatively-active gases and aerosols in the Representative Concentration Pathways, Climatic Change, 109, 191-212, doi:10.1007/s10584-011-0155-0, 2011.

Lee, B. H., Mohr, C., Lopez-Hilfiker, F. D., Lutz, A., Hallquist, M., Lee, L., Romer, P., Cohen, R. C., Iyer, S., Kurten, T., Hu, W. W., Day, D. A., Campuzano-Jost, P., Jimenez, J. L., Xu, L., Ng, N. L., Guo, H., Weber, R. J., Wild, R. J., Brown, S. S., Koss, A., de Gouw, J., Olson, K., Goldstein, A. H., Seco, R., Kim, S., McAvey, K. M., Shepson, P. B., Starn, T., Baumann, K., Edgerton, E., Liu, J., Shilling, J. E., Miller, D. O., Brune, W. H., Schobesberger, S., D'Ambro, E. L., and Thornton, J. A.: Highly functionalized organic nitrates in the Southeast U.S.: contribution to secondary organic aerosol and reactive nitrogen budgets, Proc. Natl. Acad. Sci., 113, 1516-1521, doi:10.1073/pnas.1508108113, 2016.

Lee, L., Teng, A. P., Wennberg, P. O., Crounse, J. D., and Cohen, R. C.: On Rates and Mechanisms of $\mathrm{OH}$ and $\mathrm{O} 3$ Reactions with Isoprene-Derived Hydroxy Nitrates, J. Phys. Chem. A, 118, 1622-1637, doi:10.1021/jp4107603, 2014.

Li, J., Mao, J., Pollack, I. B., Ryerson, T. B., Wolfe, G. M., Cohen, R. C., and Horowitz, L. W.: Decadal change of organic nitrates and ozone over eastern US, in preparation, 2016.

Liang, J., Horowitz, L. W., Jacob, D. J., Wang, Y., Fiore, A. M., Logan, J. A., Gardner, G. M., and Munger, J. W.: Seasonal budgets of reactive nitrogen species and ozone over the United States, and export fluxes to the global atmosphere, J. Geophys. Res.-Atmos., 103, 13435-13450, 1998.

Lin, G., Penner, J. E., Sillman, S., Taraborrelli, D., and Lelieveld, J.: Global modeling of SOA formation from dicarbonyls, epoxides, organic nitrates and peroxides, Atmos. Chem. Phys., 12, 47434774, doi:10.5194/acp-12-4743-2012, 2012.
Liu, S., Shilling, J. E., Song, C., Hiranuma, N., Zaveri, R. A., and Russell, L. M.: Hydrolysis of Organonitrate Functional Groups in Aerosol Particles, Aerosol Sci. Technol., 46, 1359-1369, doi:10.1080/02786826.2012.716175, 2012.

Lockwood, A. L., Filley, T. R., Rhodes, D., and Shepson, P. B.: Foliar uptake of atmospheric organic nitrates, Geophys. Res. Lett., 35, 115809, doi:10.1029/2008GL034714, 2008.

Lockwood, A. L., Shepson, P. B., Fiddler, M. N., and Alaghmand, M.: Isoprene nitrates: preparation, separation, identification, yields, and atmospheric chemistry, Atmos. Chem. Phys., 10, 6169-6178, doi:10.5194/acp-10-6169-2010, 2010.

Mao, J., Paulot, F., Jacob, D. J., Cohen, R. C., Crounse, J. D., Wennberg, P. O., Keller, C. A., Hudman, R. C., Barkley, M. P., and Horowitz, L. W.: Ozone and organic nitrates over the eastern United States: Sensitivity to isoprene chemistry, J. Geophys. Res.-Atmos., 118, 11256-11268, doi:10.1002/jgrd.50817, 2013.

Marais, E. A., Jacob, D. J., Jimenez, J. L., Campuzano-Jost, P., Day, D. A., Hu, W., Krechmer, J., Zhu, L., Kim, P. S., Miller, C. C., Fisher, J. A., Travis, K., Yu, K., Hanisco, T. F., Wolfe, G. M., Arkinson, H. L., Pye, H. O. T., Froyd, K. D., Liao, J., and McNeill, V. F.: Aqueous-phase mechanism for secondary organic aerosol formation from isoprene: application to the southeast United States and co-benefit of SO2 emission controls, Atmos. Chem. Phys., 16, 1603-1618, doi:10.5194/acp-16-16032016, 2016.

Monks, P. S., Archibald, A. T., Colette, A., Cooper, O., Coyle, M., Derwent, R., Fowler, D., Granier, C., Law, K. S., Mills, G. E., Stevenson, D. S., Tarasova, O., Thouret, V., von Schneidemesser, E., Sommariva, R., Wild, O., and Williams, M. L.: Tropospheric ozone and its precursors from the urban to the global scale from air quality to short-lived climate forcer, Atmos. Chem. Phys., 15, 8889-8973, doi:10.5194/acp-15-8889-2015, 2015.

Müller, J.-F., Peeters, J., and Stavrakou, T.: Fast photolysis of carbonyl nitrates from isoprene, Atmos. Chem. Phys., 14, 2497 2508, doi:10.5194/acp-14-2497-2014, 2014.

Ng, N. L., Kwan, A. J., Surratt, J. D., Chan, A. W. H., Chhabra, P. S., Sorooshian, A., Pye, H. O. T., Crounse, J. D., Wennberg, P. O., Flagan, R. C., and Seinfeld, J. H.: Secondary organic aerosol (SOA) formation from reaction of isoprene with nitrate radicals $\left(\mathrm{NO}_{3}\right)$, Atmos. Chem. Phys., 8, 4117-4140, doi:10.5194/acp-84117-2008, 2008.

Nguyen, T. B., Crounse, J. D., Schwantes, R. H., Teng, A. P., Bates, K. H., Zhang, X., St. Clair, J. M., Brune, W. H., Tyndall, G. S., Keutsch, F. N., Seinfeld, J. H., and Wennberg, P. O.: Overview of the Focused Isoprene eXperiment at the California Institute of Technology (FIXCIT): mechanistic chamber studies on the oxidation of biogenic compounds, Atmos. Chem. Phys., 14, 1353113549, doi:10.5194/acp-14-13531-2014, 2014.

Nguyen, T. B., Crounse, J. D., Teng, A. P., Clair, J. M. S., Paulot, F., Wolfe, G. M., and Wennberg, P. O.: Rapid deposition of oxidized biogenic compounds to a temperate forest, Proc. Natl. Acad. Sci., 112, E392-E401, doi:10.1073/pnas.1418702112, 2015.

Nozière, B., Barnes, I., and Becker, K.-H.: Product study and mechanisms of the reactions of $\alpha$-pinene and of pinonaldehyde with OH radicals, J. Geophys. Res.-Atmos., 104, 23645-23656, 1999.

O’Brien, J., Shepson, P., Muthuramu, K., Hao, C., Niki, H., Hastie, D., Taylor, R., and Roussel, P.: Measurements of alkyl and multifunctional organic nitrates at a rural site in Ontario, J. Geophys Res., 100, 22795-22804, 1995. 
Palmer, P. I., Abbot, D. S., Fu, T.-M., Jacob, D. J., Chance, K., Kurosu, T. P., Guenther, A., Wiedinmyer, C., Stanton, J. C., Pilling, M. J., Pressley, S. N., Lamb, B., and Sumner, A. L.: Quantifying the seasonal and interannual variability of North American isoprene emissions using satellite observations of the formaldehyde column, J. Geophys. Res., 111, D12315, doi:10.1029/2005jd006689, 2006.

Patchen, A. K., Pennino, M. J., Kiep, A. C., and Elrod, M. J.: Direct kinetics study of the product-forming channels of the reaction of isoprene-derived hydroxyperoxy radicals with NO, Int. J. Chem. Kinet., 39, 353-361, doi:10.1002/kin.20248, 2007.

Paulot, F., Crounse, J. D., Kjaergaard, H. G., Kroll, J. H., Seinfeld, J. H., and Wennberg, P. O.: Isoprene photooxidation: new insights into the production of acids and organic nitrates, Atmos. Chem. Phys., 9, 1479-1501, doi:10.5194/acp-9-1479-2009, 2009.

Paulot, F., Henze, D. K., and Wennberg, P. O.: Impact of the isoprene photochemical cascade on tropical ozone, Atmos. Chem. Phys., 12, 1307-1325, doi:10.5194/acp-12-1307-2012, 2012.

Peeters, J., Müller, J.-F., Stavrakou, T., and Nguyen, V. S.: Hydroxyl Radical Recycling in Isoprene Oxidation Driven by Hydrogen Bonding and Hydrogen Tunneling: The Upgraded LIM1 Mechanism, J. Phys. Chem. A, 118, 8625-8643, doi:10.1021/jp5033146, 2014.

Perring, A. E., Bertram, T. H., Wooldridge, P. J., Fried, A., Heikes, B. G., Dibb, J., Crounse, J. D., Wennberg, P. O., Blake, N. J., Blake, D. R., Brune, W. H., Singh, H. B., and Cohen, R. C.: Airborne observations of total $\mathrm{RONO}_{2}$ : new constraints on the yield and lifetime of isoprene nitrates, Atmos. Chem. Phys., 9, 14511463, doi:10.5194/acp-9-1451-2009, 2009a.

Perring, A. E., Wisthaler, A., Graus, M., Wooldridge, P. J., Lockwood, A. L., Mielke, L. H., Shepson, P. B., Hansel, A., and Cohen, R. C.: A product study of the isoprene $+\mathrm{NO}_{3}$ reaction, Atmos. Chem. Phys., 9, 4945-4956, doi:10.5194/acp-9-4945-2009, 2009b.

Perring, A. E., Pusede, S. E., and Cohen, R. C.: An Observational Perspective on the Atmospheric Impacts of Alkyl and Multifunctional Nitrates on Ozone and Secondary Organic Aerosol, Chem. Rev., 113, 5848-5870, doi:10.1021/cr300520x, 2013.

Pye, H. O. T., Luecken, D. J., Xu, L., Boyd, C. M., Ng, N. L., Baker, K. R., Ayres, B. R., Bash, J. O., Baumann, K., Carter, W. P. L., Edgerton, E., Fry, J. L., Hutzell, W. T., Schwede, D. B., and Shepson, P. B.: Modeling the Current and Future Roles of Particulate Organic Nitrates in the Southeastern United States, Environ. Sci. Technol., 9, 14195-14203, doi:10.1021/acs.est.5b03738, 2015.

Rindelaub, J. D., McAvey, K. M., and Shepson, P. B.: The photochemical production of organic nitrates from $\alpha$-pinene and loss via acid-dependent particle phase hydrolysis, Atmos. Environ., 100, 193-201, doi:10.1016/j.atmosenv.2014.11.010, 2015.

Roberts, J. M. and Fajer, R. W.: UV absorption cross sections of organic nitrates of potential atmospheric importance and estimation of atmospheric lifetimes, Environ. Sci. Technol., 23, 945951, 1989

Rollins, A. W., Kiendler-Scharr, A., Fry, J. L., Brauers, T., Brown, S. S., Dorn, H.-P., Dubé, W. P., Fuchs, H., Mensah, A., Mentel, T. F., Rohrer, F., Tillmann, R., Wegener, R., Wooldridge, P. J., and Cohen, R. C.: Isoprene oxidation by nitrate radical: alkyl nitrate and secondary organic aerosol yields, Atmos. Chem. Phys., 9, 6685-6703, doi:10.5194/acp-9-6685-2009, 2009.
Rollins, A. W., Smith, J. D., Wilson, K. R., and Cohen, R. C.: Real Time In Situ Detection of Organic Nitrates in Atmospheric Aerosols, Environ. Sci. Technol., 44, 5540-5545, doi:10.1021/es100926x, 2010.

Rollins, A. W., Browne, E. C., Min, K.-E., Pusede, S. E., Wooldridge, P. J., Gentner, D. R., Goldstein, A. H., Liu, S., Day, D. A., Russell, L. M., and Cohen, R. C.: Evidence for NOx Control over Nighttime SOA Formation, Science, 337, 1210-1212, doi:10.1126/science.1221520, 2012.

Rollins, A. W., Pusede, S., Wooldridge, P., Min, K.-E., Gentner, D. R., Goldstein, A. H., Liu, S., Day, D. A., Russell, L. M., Rubitschun, C. L., Surratt, J. D., and Cohen, R. C.: Gas/particle partitioning of total alkyl nitrates observed with TDLIF in Bakersfield, J. Geophys. Res.-Atmos., 118, 6651-6662, doi:10.1002/jgrd.50522, 2013.

Romer, P. S., Duffey, K. C., Wooldridge, P. J., Allen, H. M., Ayres, B. R., Brown, S. S., Brune, W. H., Crounse, J. D., de Gouw, J., Draper, D. C., Feiner, P. A., Fry, J. L., Goldstein, A. H., Koss, A., Misztal, P. K., Nguyen, T. B., Olson, K., Teng, A. P., Wennberg, P. O., Wild, R. J., Zhang, L., and Cohen, R. C.: The Lifetime of Nitrogen Oxides in an Isoprene Dominated Forest, Atmos. Chem. Phys. Discuss., doi:10.5194/acp-2016-28, in review, 2016.

Schwantes, R. H., Teng, A. P., Nguyen, T. B., Coggon, M. M., Crounse, J. D., Clair, J. M. S., Zhang, X., Schilling, K. A., Seinfeld, J. H., and Wennberg, P. O.: Isoprene $\mathrm{NO}_{3}$ Oxidation Products from the $\mathrm{RO}_{2}+\mathrm{HO}_{2}$ Pathway, The J. Phys. Chem. A, 119, 10158-10171, doi:10.1021/acs.jpca.5b06355, 2015.

SEAC4RS Field Campaign Data: SEAC4RS Field Campaign Data, doi:10.5067/Aircraft/SEAC4RS/Aerosol-TraceGas-Cloud, last modified: 11 May 2016.

Simon, H., Reff, A., Wells, B., Xing, J., and Frank, N.: Ozone Trends Across the United States over a Period of Decreasing NOx and VOC Emissions, Environ. Sci. Technol., 49, 186-195, doi:10.1021/es504514z, 2015.

Singh, H. B. and Hanst, P. L.: Peroxyacetyl nitrate (PAN) in the unpolluted atmosphere: An important reservoir for nitrogen oxides, Geophys. Res. Lett., 8, 941-944, doi:10.1029/GL008i008p00941, 1981.

Sprengnether, M., Demerjian, K. L., Donahue, N. M., and Anderson, J. G.: Product analysis of the $\mathrm{OH}$ oxidation of isoprene and 1,3-butadiene in the presence of NO, J. Geophys. Res.-Atmos., 107, ACH 8-1-ACH 8-13, doi:10.1029/2001JD000716, 2002.

Talukdar, R. K., Burkholder, J. B., Hunter, M., Gilles, M. K., Roberts, J. M., and Ravishankara, A. R.: Atmospheric fate of several alkyl nitrates Part 2UV absorption cross-sections and photodissociation quantum yields, J. Chem. Soc., Faraday Trans., 93, 2797-2805, doi:10.1039/A701781B, 1997.

Teng, A. P., Crounse, J. D., and Wennberg, P. O.: Isoprene peroxy radical dynamics, in preparation, 2016.

Toon, O. B., Maring, H., Dibb, J., Ferrare, R., Jacob, D. J., Jensen, E. J., Luo, Z. J., Mace, G. G., Pan, L. L., Pfister, L., Rosenlof, K. H., Redemann, J., Reid, J. S., Singh, H. B., Yokelson, R., Minnis, P., Chen, G., Jucks, K. W., and Pszenny, A.: Planning, implementation and scientific goals of the Studies of Emissions and Atmospheric Composition, Clouds and Climate Coupling by Regional Surveys (SEAC4RS) field mission, J. Geophys. Res., doi:10.1002/2015JD024297, online first, 2016. 
Travis, K. R., Jacob, D. J., Fisher, J. A., Kim, P. S., Marais, E. A., Zhu, L., Yu, K., Miller, C. C., Yantosca, R. M., Sulprizio, M. P., Thompson, A. M., Wennberg, P. O., Crounse, J. D., St. Clair, J. M., Cohen, R. C., Laugher, J. L., Dibb, J. E., Hall, S. R., Ullmann, K., Wolfe, G. M., Pollack, I. B., Peischl, J., Neuman, J. A., and Zhou, $\mathrm{X} . \mathrm{NO}_{x}$ emissions, isoprene oxidation pathways, vertical mixing, and implications for surface ozone in the Southeast United States, Atmos. Chem. Phys. Discuss., doi:10.5194/acp2016-110, in review, 2016.

Tuazon, E. C. and Atkinson, R.: A product study of the gas-phase reaction of Isoprene with the $\mathrm{OH}$ radical in the presence of NOx, Int. J. Chem. Kinet., 22, 1221-1236, doi:10.1002/kin.550221202, 1990.

Wainwright, C. D., Pierce, J. R., Liggio, J., Strawbridge, K. B., Macdonald, A. M., and Leaitch, R. W.: The effect of model spatial resolution on Secondary Organic Aerosol predictions: a case study at Whistler, BC, Canada, Atmos. Chem. Phys., 12, 1091110923, doi:10.5194/acp-12-10911-2012, 2012.

Wang, Y. X., McElroy, M. B., Jacob, D. J., and Yantosca, R. M.: A nested grid formulation for chemical transport over Asia: Applications to CO, J. Geophys. Res.-Atmos., 109, d22307, doi:10.1029/2004JD005237, 2004.

Wolfe, G. M., Hanisco, T. F., Arkinson, H. L., Bui, T. P., Crounse, J. D., Dean-Day, J., Goldstein, A., Guenther, A., Hall, S. R., Huey, G., Jacob, D. J., Karl, T., Kim, P. S., Liu, X., Marvin, M. R., Mikoviny, T., Misztal, P. K., Nguyen, T. B., Peischl, J., Pollack, I., Ryerson, T., St. Clair, J. M., Teng, A., Travis, K. R., Ullmann, K., Wennberg, P. O., and Wisthaler, A.: Quantifying sources and sinks of reactive gases in the lower atmosphere using airborne flux observations, Geophys. Res. Lett., 42, 8231-8240, doi:10.1002/2015GL065839, 2015.

Worton, D. R., Reeves, C. E., Penkett, S. A., Sturges, W. T., Slemr, J., Oram, D. E., Bandy, B. J., Bloss, W. J., Carslaw, N., Davey, J., Emmerson, K. M., Gravestock, T. J., Hamilton, J. F., Heard, D. E., Hopkins, J. R., Hulse, A., Ingram, T., Jacob, M. J., Lee, J. D., Leigh, R. J., Lewis, A. C., Monks, P. S., and Smith, S. C.: Alkyl nitrate photochemistry during the tropospheric organic chemistry experiment, Atmos. Environ., 44, 773-785, doi:10.1016/j.atmosenv.2009.11.038, 2010.

Xie, Y., Paulot, F., Carter, W. P. L., Nolte, C. G., Luecken, D. J., Hutzell, W. T., Wennberg, P. O., Cohen, R. C., and Pinder, R. W.: Understanding the impact of recent advances in isoprene photooxidation on simulations of regional air quality, Atmos. Chem. Phys., 13, 8439-8455, doi:10.5194/acp-13-8439-2013, 2013.

Xiong, F., McAvey, K. M., Pratt, K. A., Groff, C. J., Hostetler, M. A., Lipton, M. A., Starn, T. K., Seeley, J. V., Bertman, S. B., Teng, A. P., Crounse, J. D., Nguyen, T. B., Wennberg, P. O., Misztal, P. K., Goldstein, A. H., Guenther, A. B., Koss, A. R., Olson, K. F., de Gouw, J. A., Baumann, K., Edgerton, E. S., Feiner, P. A., Zhang, L., Miller, D. O., Brune, W. H., and Shepson, P. B.: Observation of isoprene hydroxynitrates in the southeastern United States and implications for the fate of $\mathrm{NO}_{x}$, Atmos. Chem. Phys., 15, 11257-11272, doi:10.5194/acp-15-11257-2015, 2015.
Xu, L., Guo, H., Boyd, C. M., Klein, M., Bougiatioti, A., Cerully, K. M., Hite, J. R., Isaacman-VanWertz, G., Kreisberg, N. M., Knote, C., Olson, K., Koss, A., Goldstein, A. H., Hering, S. V., de Gouw, J., Baumann, K., Lee, S.-H., Nenes, A., Weber, R. J., and Ng, N. L.: Effects of anthropogenic emissions on aerosol formation from isoprene and monoterpenes in the southeastern United States, Proc. Natl. Acad. Sci., 112, 37-42, doi:10.1073/pnas.1417609112, 2014.

Xu, L., Suresh, S., Guo, H., Weber, R. J., and Ng, N. L.: Aerosol characterization over the southeastern United States using highresolution aerosol mass spectrometry: spatial and seasonal variation of aerosol composition and sources with a focus on organic nitrates, Atmos. Chem. Phys., 15, 7307-7336, doi:10.5194/acp15-7307-2015, 2015.

Yu, K., Jacob, D. J., Fisher, J. A., Kim, P. S., Marais, E. A., Miller, C. C., Travis, K. R., Zhu, L., Yantosca, R. M., Sulprizio, M. P., Cohen, R. C., Dibb, J. E., Fried, A., Mikoviny, T., Ryerson, T. B., Wennberg, P. O., and Wisthaler, A.: Sensitivity to grid resolution in the ability of a chemical transport model to simulate observed oxidant chemistry under high-isoprene conditions, Atmos. Chem. Phys., 16, 4369-4378, doi:10.5194/acp-16-43692016, 2016.

Zhang, L., Jacob, D. J., Downey, N. V., Wood, D. A., Blewitt, D., Carouge, C. C., van Donkelaar, A., Jones, D. B., Murray, L. T., and Wang, Y.: Improved estimate of the policyrelevant background ozone in the United States using the GEOS-Chem global model with $1 / 2^{\circ} 2 / 3^{\circ}$ horizontal resolution over North America, Atmos. Environ., 45, 6769-6776, doi:10.1016/j.atmosenv.2011.07.054, 2011.

Zhang, L., Jacob, D. J., Knipping, E. M., Kumar, N., Munger, J. W., Carouge, C. C., van Donkelaar, A., Wang, Y. X., and Chen, D.: Nitrogen deposition to the United States: distribution, sources, and processes, Atmos. Chem. Phys., 12, 4539-4554, doi:10.5194/acp-12-4539-2012, 2012.

Zhu, L., Jacob, D. J., Kim, P. S., Fisher, J. A., Yu, K., Travis, K. R., Mickley, L. J., Yantosca, R. M., Sulprizio, M. P., De Smedt, I., Gonzalez Abad, G., Chance, K., Li, C., Ferrare, R., Fried, A., Hair, J. W., Hanisco, T. F., Richter, D., Scarino, A. J., Walega, J., Weibring, P., and Wolfe, G. M.: Observing atmospheric formaldehyde ( $\mathrm{HCHO}$ ) from space: validation and intercomparison of six retrievals from four satellites (OMI, GOME2A, GOME2B, OMPS) with SEAC4RS aircraft observations over the Southeast US, Atmos. Chem. Phys. Discuss., doi:10.5194/acp-2016-162, in review, 2016. 